\title{
Subsurface variations in arsenic mineralogy and geochemistry following long-term weathering of gold mine tailings
}

\author{
Stephanie L. DeSisto ${ }^{a,}{ }^{,}$, Heather E. Jamieson ${ }^{a}$, Michael B. Parsons ${ }^{b}$ \\ ${ }^{a}$ Department of Geological Sciences \& Geological Engineering, Queen’s University, Kingston, \\ Ontario, Canada K7L 3N6 \\ ${ }^{\mathrm{b}}$ Natural Resources Canada, Geological Survey of Canada (Atlantic), 1 Challenger Drive, \\ Dartmouth, Nova Scotia, Canada B2Y 4A2
}

\begin{abstract}
Variations in arsenic (As) mineralogy and geochemical controls on its mobility were evaluated in subsurface tailings at the historical Montague and Goldenville mine sites in Nova Scotia, Canada. Tailings at these sites contain some of the highest As concentrations in Nova Scotia and are located in close proximity to local communities. Pore water in the subsurface tailings is characterized by circumneutral to alkaline $\mathrm{pH}$ (6.2 to 8.7) and mildly reducing to oxidizing redox conditions $(+130 \mathrm{mV}$ to $+347 \mathrm{mV})$. Bulk chemistry, scanning electron microscopy, and synchrotron micro-X-ray diffraction analyses showed As mineral hosts differ with depth. The deepest tailings (max. $2 \mathrm{~m}$ ) are in direct contact with partially decomposed vegetation, which supports reducing conditions and the precipitation of authigenicAs and Fe sulfides. Under reducing conditions, dissolved As concentrations are also controlled by desorption of As from dissolution of Fe and Mn oxides and the sorption or co-precipitation of As with carbonates. These geochemical controls differ from those influencing dissolved As concentrations under oxidizing conditions. In the near surface, As mobility is controlled by oxidative dissolution of primary arsenopyrite, precipitation of secondary Fe arsenates, Fe oxyhydroxides and Mn oxides, secondary Ca-Fe arsenates, and sorption onto Fe oxyhydroxides and gangue minerals. Some of these mineral species are stable under different conditions yet occur in close association, indicating the importance of microenvironments. The results of this study show that
\end{abstract}


theweathering characteristics of these tailings vary with depth, leading to the formation of new As hosts that are distinct from those observed in the near surface. Identification of these As hosts provides an understanding of current controls on As mobility and has implications for future reprocessing and/or remediation efforts.

\section{Introduction}

During the process of mining, metals are extracted from ore through various crushing and refining procedures depending on ore and gangue mineralogy.The production of mine waste such as tailings and waste rock isa consistent feature of all mining operations. Tailings are normally deposited as a fine-grained sediment-water slurry (Lottermoser, 2010) where gangue and residual ore minerals, including sulfide minerals, become dispersed and can be exposed to atmospheric conditions. If $\mathrm{Fe}$ sulfide minerals are present, they may oxidize to produce acidic drainage, which can be neutralized by the occurrence of any carbonate minerals in the tailings.

Although acid mine drainage has received much attention, neutral-pH mine drainage can have similarly high dissolved metal, metalloid, and sulfate concentrations (Scharer et al. 2000;

Nordstrom 2011). Several elements (e.g. As, $\mathrm{Cd}, \mathrm{Cu}, \mathrm{Mn}, \mathrm{Se}, \mathrm{Sb}, \mathrm{U}, \mathrm{Zn}$ ) will remain mobile and can persist in high concentration under neutral pH conditions (MEND, 2004). Multiple studies have documented the occurrence of neutral mine drainage (e.g. Kwong et al., 2007; Lindsay et al., 2009; Desbarats et al., 2011; Majzlan et al., 2011; Jamieson et al. 2015). A specific example of neutral mine drainage is associated with the oxidation of As-bearing minerals in gold mine tailings (Bowell and Craw, 2014). These tailings may contain sulfides such as pyrite $\left(\mathrm{FeS}_{2}\right)$ or arsenopyrite (FeAsS) that will generate acidity and release As upon oxidation, but the tailings may also contain sufficient neutralizing potential to consume and limit acidity (Savage et al., 
2000; Haffert et al., 2010; Jamieson et al. 2015). Orogenic gold deposits, such as in the Meguma Terrane of Nova Scotia, typically have quartz-dominant vein systems with $\leq 3$ to $5 \%$ sulfide and $\leq 5$ to $15 \%$ carbonate minerals (Kontak\& Smith, 1988; Groves et al., 1998; Ryan \& Smith, 1998). Gangue and alteration minerals include muscovite, chlorite, plagioclase, biotite, amphibole, tourmaline and Ca-Mg-Fe carbonates (Kontak\& Smith, 1988; Seal \&Hammarstrom, 2003).Orogenic gold mine drainage typically has a pH range between 4.5 and 8.5 (Seal \&Hammarstrom, 2003). These higher $\mathrm{pH}$ values reflect the abundance of carbonate minerals relative to minor amounts of sulfide minerals within these deposits.

From 1861 to the mid-1940s gold was produced from 64 mining districts across the Province of Nova Scotia, Canada (Bates, 1987), generating more than three million tonnes of tailings. Since deposition, sulfide minerals within these tailings have been oxidizing and releasing As to pore waters. Surface water samples $(\mathrm{n}=181)$ collected from nine of these mine sites between 2003 and 2005 show median dissolved As concentrations of $117 \mu \mathrm{g} / \mathrm{L}$ (range 0.2 to $6580 \mu \mathrm{g} / \mathrm{L}$ ) whereas baseline levels are $<25 \mu \mathrm{g} / \mathrm{L}$ (Parsons et al., 2012). The surface waters are generally circumneutral to slightly acidic (median pH 6.1). At the Montague and Goldenville sites, median tailings pore water $\mathrm{pH}$ is 6.6 and ranges from 2.1 to 8.7 (DeSisto et al., 2011). The more acidic $\mathrm{pH}$ values occur where sulfide concentrate co-disposed with the tailings has weathered into hardpan layers cemented by secondary Fe arsenate and Fe oxide minerals (DeSisto et al., 2011).

The strongly weathered surface horizons in these tailings generally do not extend more than a meter deep. However, most previous studies of tailings geochemistry and mineralogy (e.g., Walker et al. 2009; Corriveau et al. 2011b; DeSisto et al. 2011; Percival et al. 2013) have focused on this relatively narrow layer of weathered material. The surface tailings are significant 
for being host to high As concentrations, which has implications for human and other bioreceptor exposure (Meunier et al. 2010; Saunders et al. 2011), but the subsurface tailings represent most of the total volume, and are expected to have a significant influence on groundwater As concentrations. There is a need to characterize the mineral hosts for As in the subsurface material to better understand the existing controls on As mobility and implications for future reprocessing and/or remediation of the tailings across Nova Scotia and at similar sites worldwide.

The first objective of this study was to document the variation in As-hosting minerals in the subsurface tailings and determine if these tailings reflect the varied tailings types identified in the near-surface by Walker et al. (2009). The second aim was to identify present-day geochemical controls on As mobility in the subsurface tailings and in the non-hardpan surface tailings to gain a better understanding of the overall stability of solid phase hosts for As, and what this means in terms of As release to local ground and surface waters. Water chemistry of these tailings has been reported previously (DeSisto et al., 2011; Parsons et al., 2012), but it has not been linked to the distinct tailings types, with the exception of hardpan tailings.

\section{Field methods}

\subsection{Study sites and targeted tailings types}

Sample locations in the current study were chosen from two former Nova Scotia gold mines that are located close to residential areas. Montague Gold Mines (Fig. 1a) is a suburban community located just outside the urban core of Halifax Regional Municipality. The mine site consists of two main tailings flats separated by a thin line of trees with denser forest separating the nearest homes from the tailings. The Goldenville district (Fig. 1b) is located $3 \mathrm{~km}$ west of the community of Sherbrooke along the eastern shore of Nova Scotia. This area is more rural compared to Montague but there are homes within 100 to $200 \mathrm{~m}$ of the tailings at both locations. 
Waste rock piles exist throughout both sites along with the remnants of various stamp mill foundations. Both sites are frequented as recreational areas where local residents use all-terrain vehicles and dirt bikes.

The sampling program was designed to collect solids and water samples from four types of tailings defined on the basis of previous work (Walker et al. 2009; DeSisto et al. 2011) and consideration of field setting, bulk composition, and As mineralogy as: 1) hardpan tailings, 2) oxic tailings, 3) wetland tailings, and 4) high-Ca tailings. These are related to the six types described by Walker et al. (2009), but we combined their "arsenopyrite-rich mill concentrate," "mill concentrate that has completely oxidized to scorodite," and "tailings dominated by ferric arsenate minerals that have become cemented into hardpan layers" into hardpan tailings and simplified the names of the other three. These near-surface tailings types were compared to subsurface tailings collected at depth. The upper limit of the subsurface tailings was based on field observations of where the tailings became saturated and/or no longer showed oxidation features.

\subsection{Water samples}

Vadose zone waters in the tailings were sampled using $94 \mathrm{~cm}$ long PVC suction lysimeters (Soil Moisture Equipment Corporation, Model 1920 F1/K1 Pressure-Vacuum Soil Water Sampler) from six Montague sample locations (Fig. 1a) at depths between 9 and $17 \mathrm{~cm}$. Goldenville vadose zone samples were collected from nine sample locations (Fig. 1b) at depths between 19 and $40 \mathrm{~cm}$. Saturated zone waters were collected via drivepoint piezometers and a peristaltic pump (Solinst Model 410). Montague samples were acquired from depths between 70 and $125 \mathrm{~cm}$ and from Goldenville at depths between 60 and $146 \mathrm{~cm}$. The vadose zone and saturated zone sampling depths were based on water table height at the time of sampling. 
Measurements of temperature, $\mathrm{pH}$, Eh, dissolved oxygen (DO), and specific conductance (SC) were made immediately after collection. All waters were split into aliquots for analyses of metals, anions, As speciation, Fe and S speciation, and alkalinity. All saturated zone waters were filtered with $0.45 \mu \mathrm{m}$ syringe filters and vadose zone waters were considered to be effectively filtered to $0.45 \mu \mathrm{m}$ by the porous ceramic cup on the lysimeters. Samples intended for metals analyses were acidified to $1 \%$ with $8 \mathrm{~N}$ Optima-grade $\mathrm{HNO}_{3}$. One As speciation aliquot was preserved to $1 \%$ acidity with $12 \mathrm{~N}$ Optima-grade $\mathrm{HCl}$ and another aliquot was cryogenically preserved by flash freezing in dry ice. Only saturated zone samples were cryogenically preserved because only these samples were expected to potentially contain thioarsenic species (PlanerFriedrich et al., 2007; Wallschläger\&Stadey, 2007). Determination of Fe(II) and S(-II) was made by spectrophotometry (HACH DR/2400) on unpreserved samples within $6 \mathrm{~h}$ of sample collection.To prevent oxidation of reduced Fe and S species, sample bottles were filled completely, tightly capped, and stored in a cool and dark place until analysis. Due to the length of time between collection and analysis, S(-II) concentrations and $\mathrm{Fe}(\mathrm{II}) / \mathrm{Fe}(\mathrm{III})$ ratios may be slightly higher than reported in Tables S3 and S4, Supplementary Material.

\subsection{Tailings cores}

Hand-driven core samples of tailings were obtained at each of the pore water sampling sites. Core tubes were $4.5 \mathrm{~cm}$ inner diameter aluminum and in most cases, a $60 \mathrm{~cm}-\mathrm{long}$ section was driven into the tailings first to collect a near-surface sample. This sample was thenremoved and a $120 \mathrm{~cm}$-long tube was inserted where the shorter section ended. A total of nine cores were collected from Montague and 17 cores from Goldenville.Cores were collected from sites interpreted to be hardpan, oxic, and Ca-rich tailings based on field characteristics. No cores were collected from wetland tailings. After collection, the cores were immediately cut into 
sectionswith a core cutter to fit into coolers and all ends were sealed before the cores were frozen. Prior to analysis, the cores were split by cutting through the metal with a table-top circular saw and allowed to thaw before being pried apart with a drywall scraper. Near-surface cores were allowed to thaw and dry in the lab under ambient conditions and deeper cores were dried in a glove bag under flowing $\mathrm{N}_{2}$.

\section{Field sample analyses}

\subsection{Dissolved elements and anions}

Dissolved elements (Ag, Al, As, B, Ba, Be, Ca, Cd, Co, Cr, Cu, Fe, K, Mg, Mn, Mo, Na, $\mathrm{Ni}, \mathrm{P}, \mathrm{Pb}, \mathrm{S}, \mathrm{Sb}, \mathrm{Se}, \mathrm{Si}, \mathrm{Sn}, \mathrm{Sr}, \mathrm{Ti}, \mathrm{Tl}, \mathrm{U}, \mathrm{V}, \mathrm{Zn}$ ) were determined by ICP-OES (Varian AX-Vista Pro CCD Simultaneous ICP-OES) at the Analytical Services Unit (ASU), Queen's University. Field duplicates were precise to $\pm 10 \%$ except for two samples which showed $>15 \%$ Relative Standard Deviation (RSD) for As and Fe. Lab duplicates were precise to $\pm 10 \%$.

Anions $\left(\mathrm{Cl}^{-}, \mathrm{F}^{-}, \mathrm{NO}_{2}{ }^{-}, \mathrm{NO}_{3}{ }^{-}, \mathrm{SO}_{4}{ }^{2-}\right)$ were measured by ion chromatography (Dionex DX3000) at ASU, Queen's University. Lab duplicates were precise to $\pm 10 \%$. Field duplicates were $\pm 10 \%$ except for two $\mathrm{SO}_{4}{ }^{2-}$ samples. The QA/QC results for metals and anions both suggest samples from MGL6 and GVL9 show discrepancies between duplicate samples, likely due to sample heterogeneity.

\subsection{Speciation}

Arsenic speciation was determined by Ion Chromatography - Inductively Coupled Plasma Mass Spectroscopy (IC-ICP-MS) (ELAN DRC II) at the Trent Water Quality Centre, Trent University. The cryogenically preserved waters were thawed in a glove box $\left(\mathrm{N}_{2} / \mathrm{H}_{2}\right.$ mixture) and any dilutions were performed with $\mathrm{N}_{2}$-bubbled water. Precision for As(III) was 
$\pm 10 \%$ for all duplicates except for three samples. The cryogenically preserved samples from all saturated zone samples gave better precision for As(III) than traditionally preserved samples. Based on this, the cryogenic results are used for saturated zone speciation results and for total dissolved As.

\subsection{Aqueous Speciation Modeling}

Aqueous speciation calculations were completed in the geochemical modeling program PHREEQC (Parkhurst \&Appelo, 2013). The measured pH, redox, alkalinity, and soluble metal concentrations from vadose zone and saturated zone pore waters were used as inputs and the standard WATEQ4F database (Ball \& Nordstrom, 1991) in PHREEQC was used for

calculations. In addition, the following data were added for lepidocrocite: $\mathrm{FeOOH}+3 \mathrm{H}^{+}=\mathrm{Fe}^{3+}$ $+2 \mathrm{H}_{2} \mathrm{O}, \log \mathrm{k}=3.7$ (Hashimoto \& Misawa, 1973), and for green rust: $\mathrm{Fe}_{6}(\mathrm{OH})_{12} \mathrm{CO}_{3}+13 \mathrm{H}^{+}=$ $4 \mathrm{Fe}^{2+}+2 \mathrm{Fe}^{3+}+\mathrm{HCO}_{3}^{-}+12 \mathrm{H}_{2} \mathrm{O}, \log \mathrm{k}=39.1$ (Rickard \& Luther, 2007).

\section{Solid phase analyses}

\subsection{Bulk chemistry}

Cores were subsampled to obtain solids at the same depth as the pore water samples and at additional depths to identify variations in As mineralogy. The subsamples were chosen to provide representative examples of the tailings types found at each sample location, but may not capture the full variability in grain size or other physical features in the tailings at each site. Where present, organic material at the base of cores, likely representing wetland vegetation on which tailings were originally deposited, was subsampled and labeled OM. At least $0.5 \mathrm{~g}$ of each subsample was sent to ACME Analytical Laboratories, Vancouver, BC for bulk chemical analysis. An aqua regia digestion followed by ICP-MS (Perkin Elmer 6000 or 9000) analysis 
was performed for a 37-element suite (Al, Ag, As, $\mathrm{Au}, \mathrm{B}, \mathrm{Ba}, \mathrm{Bi}, \mathrm{Ca}, \mathrm{Co}, \mathrm{Cr}, \mathrm{Cu}, \mathrm{Cd}, \mathrm{Fe}, \mathrm{Ga}$, Hg, K, La, Mg, Mn, Mo, Na, Ni, P, Pb, S, Sb, Sc, Se, Sr, Te, Th, Ti, Tl, U, V, W, Zn). Samples found to have As concentrations greater than the limit of quantitation $(10,000 \mathrm{mg} / \mathrm{kg})$ underwent a hot aqua regia digestion and analysis by ICP-ES (SpectroCiros Vision ICP-ES). Two certified sediment samples (CANMET STSD-1, STSD-4; Lynch, 1990) were included as blind reference material throughout the samples. Sample blanks, replicates, and standard reference materials were included for the in-house lab QA/QC. The CANMET certified reference materials showed accuracy within $\pm 10 \%$ of expected values except for $\mathrm{Ag}, \mathrm{As}, \mathrm{Co}, \mathrm{Cu}, \mathrm{Cr}, \mathrm{Fe}, \mathrm{Hg}, \mathrm{Pb}, \mathrm{Ni}, \mathrm{Sb}, \mathrm{V}$, $\mathrm{Zn}( \pm 15 \%)$ in some samples, and $\mathrm{As}, \mathrm{Cd}, \mathrm{Hg}, \mathrm{Sb}, \mathrm{V}( \pm 20 \%)$ in some samples. Certified reference materials analyzed near the end of the run showed greater inaccuracy, which is likely due to carry over from previous samples with high $\mathrm{As}, \mathrm{Cd}, \mathrm{Hg}$, and/or Mo concentrations. This does not significantly affect interpretations as the bulk concentrations of these elements are high. The full analytical dataset for all samples and certified reference materials analyzed during this study is provided in DeSisto (2014).

\subsection{Carbon}

Subsamples $(0.5$ to $1.0 \mathrm{~g})$ from cores were analyzed at the Geological Survey of Canada (Atlantic) for carbon using a LecoTruSpec CHN instrument. A portion of each subsample was analyzed for total carbon and the other portion was leached overnight with $10 \% \mathrm{HCl}$ to remove inorganic carbon (IC) and analyzed for organic carbon (OC). Inorganic carbon was calculated by difference.Precision and accuracy were approximately $\pm 0.05 \mathrm{wt} . \%$ based on replicate analyses of calibration standards. 


\subsection{Environmental Scanning Electron Microscopy}

Thin sections were prepared by making epoxy plugs of sub-samples from the cores following methods described in Walker et al. (2005). This method is designed to preserve stratigraphic relationships within the tailings (i.e. $\mathrm{mm}$ - to $\mathrm{cm}$-scale banding) as well as delicate grain coatings. The samples were doubly polished andremovable from glass slides for subsequent scanning electron microscopy and synchrotron-based analyses.

Mineral identification was aided by back-scattered electron images and energy-dispersive spectra acquired using a FEI-MLA Quanta 650 FEG ESEM at Queen's University. The spectra were used to identify major element composition and targets for subsequent synchrotron-based analyses. Thin sections were not carbon coated to simplify the identification of targets at thesynchrotron.

\subsection{Synchrotron-based microanalytical methods}

Previous work (Walker et al. 2005, 2009; DeSisto et al. 2011; Jamieson, 2011) has shown that grain-scale X-ray diffraction of targets selected from multi-element X-ray fluorescence maps generated from focused synchrotron X-ray sources is an effective means of identifying Ashosting phases that are rare, fine-grained, and difficult to locate. To prepare for this work, polished thin sections were removed from petrographic slides by soaking in acetone (HPLC grade). The sections were then affixed to Kapton tape stabilized in $35 \mathrm{~mm}$ slide holders (cf. Walker et al., 2005). Micro-X-ray diffraction and X-ray fluorescence mapping were conducted at beamline X26A at the National Synchrotron Light Source, Upton, NY. Analysis was in fluorescence mode with a beam spot size of $5 \times 9 \mu \mathrm{m}$. Diffraction patterns were collected above the As K-edge at ca. $17 \mathrm{keV}(0.70931 \AA)$ for an exposure time of $60 \mathrm{~s}$. A blank $\mu$ XRD pattern of Kapton was collected for background subtraction of the unknown patterns. Targets for 
$\mu \mathrm{XRDwere}$ chosen based on the ratio of Fe:As:Ca counts and element relationships on $\mu \mathrm{XRF}$ maps. The Fit2D software (Hammersley, 1998) was used for background subtraction and masking beam-sample interactions. Mineral identification was performed by pattern-matching using the HighScore software and reference patterns from the International Centre for Diffraction Data database (ICDD, 2003).

\section{Results}

\subsection{Tailings bulk chemistry and tailings types}

Selected bulk chemistry and carbon results are compiled in Table S1 (Supplementary Material) for Montague samples and Table S2 (Supplementary Material)for Goldenville samples. Within these tables, the near-surface (i.e. generally unsaturated) tailings are identified as one of the four tailings types based on field characteristics (e.g. color, grain size) and geochemical results, as shown in Fig. 2. Deeper tailings not assigned to a tailings type are referred to as subsurface tailings. The highest As from the near-surface tailings is from hardpan samples at $>200,000 \mathrm{mg} / \mathrm{kg}$ As (median 79,800 mg/kg; $\mathrm{n}=13$ ). Lowest bulk As values are from the high $\mathrm{Ca}$ tailings (median $1650 \mathrm{mg} / \mathrm{kg}$; $\mathrm{n}=8$ ). Like As, Fe exceeds 200,000 mg/kg in hardpan samples (median 90,100 mg/kg), whereas the lowest Fe concentrations are from high $\mathrm{Ca}$ (median 30,150 $\mathrm{mg} / \mathrm{kg}$ ) and oxic (median 32,700 mg/kg; $\mathrm{n}=22$ ) tailings samples. The lowest $\mathrm{S}$ values are also from oxic (median $600 \mathrm{mg} / \mathrm{kg}$ ) and high $\mathrm{Ca}$ (median $1100 \mathrm{mg} / \mathrm{kg}$ ) tailings and the highest $\mathrm{S}$ values $(>30,000 \mathrm{mg} / \mathrm{kg}$ ) are from hardpan tailings (median $5700 \mathrm{mg} / \mathrm{kg}$ ).

Subsurface tailings show As and Ca values range between 450 - 13,000 mg/kg (median As $2285 \mathrm{mg} / \mathrm{kg}$; median Ca $3100 \mathrm{mg} / \mathrm{kg}$; $\mathrm{n}=34$ ). Iron concentrations are higher and range from 12,000 to almost $40,000 \mathrm{mg} / \mathrm{kg}$ (median $29,800 \mathrm{mg} / \mathrm{kg}$ ). Sulfur varies from less than detection $(<200 \mathrm{mg} / \mathrm{kg}$ ) to $13,600 \mathrm{mg} / \mathrm{kg}$ (median $2150 \mathrm{mg} / \mathrm{kg}$ ). The median OC content in subsurface 
tailings is $0.08 \%$ but ranges from $0.004-0.8 \%$. Inorganic carbon ranges from less than detection $(0.01 \%)$ to $0.5 \%$ (median $0.15 \%)$.

Representative examples of the distribution of tailings geochemistry with depth at each sample location, based on physical observations from cores and the bulk analytical results, are depicted in Fig. 3. The near-surface samples are identified as hardpan, oxic tailings (which also occur below hardpan), and high-Ca tailings.

\subsubsection{Subsurface tailings with hardpan tailings near surface}

Relative to the near-surface hardpan-bearing tailings, the tailings at depth below the hardpan have lowerAs, Fe, and S bulk concentrations and higher concentrations ofCa, OC, and IC. Sulfur increases only within the deepest tailings at the tailings-OM interface. Table 1 shows correlation coefficients between the key variables in Tables S1 and S2 (Supplementary Material). Where hardpan occurs at surface (e.g. Fig. 3a),there is a strong positive relationship with depth for As and $\mathrm{Fe}$ and a more variable but positive relationship for As and $\mathrm{S}$ as well as $\mathrm{Fe}$ and $\mathrm{S}$, reflecting the abundance of sulfide concentrate that was deposited on top of the tailings and subsequently oxidized since the end of mining (DeSisto et al. 2011). Arsenic and Ca have a negative relationship from the Montague tailings but a strong positive relationship in the Goldenville tailings. This likely reflects higher carbonate content in the original ore at Goldenville. Calcium association with OC and IC shows a variable relationship with depth but most locations have a stronger positive trend for $\mathrm{Ca}$ and $\mathrm{IC}$ than $\mathrm{Ca}$ and $\mathrm{OC}$.

\subsubsection{Subsurface tailings with oxic tailings near surface}

Where oxic tailings occur near surface (e.g. Fig. 3b), As and Fe generally decrease with depth and show a positive relationship with only GVL9 having a negative trend with depth.All of 
the p-values for the As-Fe comparison, as well as the Fe-S comparison, indicate a significant relationship. The relationship between As-S, as well as Fe-S, with depth varies from strongly positive (GVL8, GVL4) to strongly negative (GVL3). In other locations, there is no trend between Fe and S with depth (MGL6, GVL5). Arsenic and Ca have a negative or no relationship with depth at all of the Montague sample locations and at GVL9. In contrast, the other Goldenville locations have a positive As and Ca relationship with depth. However, p-values indicate there is not a significant correlation between As and Ca with depth in these tailings. None of the oxic tailings show a strong positive or negative correlation for $\mathrm{Ca}$ and $\mathrm{OC}$ but they do show both trends for $\mathrm{Ca}$ and IC.

\subsubsection{Subsurface tailings with high Ca tailings near surface}

For areaswith high Ca tailings near surface (e.g. Fig. 3c) As increases with depth at GVL6 but remains the same with depth at GVL7. Iron shows relatively little change with depth. At GVL6, S increases to $1 \mathrm{wt} . \%$ around $80 \mathrm{~cm}$ but otherwise decreases with depth, as it does at

GVL7. Calcium, OC, and IC all decrease with depth at GVL6 whereas Ca and OC increase with depth at GVL7. Inorganic C remains generally the same with depth at GVL7.

Correlations with high Ca tailings near surface show similar trends for As-Fe, As-Ca, and $\mathrm{Ca}-\mathrm{OC}$ as all having moderately positive relationships with depth, based on correlation coefficients (Table 1). Arsenic and S, and Fe-S from GVL6 have a positive correlation with depth. Conversely, As-S shows a negative correlation with depth at GVL7 and no correlation between Fe-S. Tailings from both of these sample locations show a positive trend with depth for Ca-IC. The p-values from these comparisons indicate As-Fe, Fe-S, Ca-OC, and Ca-IC have significant correlations with depth. 
Important points from this analysis are that all subsurface tailings below oxic tailings show both positive and negative significant correlations for As and Fe. Only Goldenville subsurface tailings below hardpan have significant and positive correlations for As with S and As with $\mathrm{Ca}$. Subsurface tailings below high Ca tailings show significant negative correlations for As with Fe. This variability reflects tailings heterogeneity with depth.

\subsection{Tailings mineralogy}

Previous work (Walker et al. 2009; Corriveau et al. 2011a,b; DeSisto et al. 2011) has identified multiple As-bearing minerals as weathering products of arsenopyrite in near-surface Nova Scotia gold mine tailings. For this study, As mineralogy was determined at sample locations considered representative of the four main tailings types at surface and in selected subsurface tailings samples.

\subsubsection{Montague tailings}

The surface oxic tailingssample from MGL2 $(8-12 \mathrm{~cm})$ contains arsenopyrite, As-bearing Fe oxides, and grains coated or rimmed with an Fe-As phase, as identified by ESEM. MicroXRD was used to identifyscorodite, yukoniteand gangue minerals (muscovite, clinochlore, albite, quartz, illite). Arsenic seems to be sorbed to at least some of these gangue minerals as they showed elevated As counts on element maps, which has also been reported by Walker et al. (2009) for near-surface forest soil samples from Nova Scotia. Other researchers have reported an association of As and clay minerals (Lin \&Puls, 2000; García-Sanchez et al., 2002; Goldberg, 2002). Arsenic hosts in the fine grained deeper tailings at MGL2 (95-99 cm) include arsenopyrite and Fe-As-Ni-Co grains. This sample is from the tailings-OM interface and also contains nonAs-bearing framboidal pyrite associated with plant material at this boundary. 
The near-surface oxictailings (20-24 cm) at MGL5 contain Fe-Ca-As coatings on gangue minerals,silicate grains rimmed or coated with an As-bearing Fe-Mn ( \pm Ca) phase (Fig. 4a,b,c), and primary sulfides of arsenopyrite and arsenian pyrite showing weathered edges. Most often, weathered arsenopyrite showed a greater degree of replacement than pyrite.X-ray fluorescence maps from these samples identifiedthe majority of As-bearing grains as muscovite, but they also includeanorthite, illite, clinochlore, and chlorite-serpentine. This suggests As may be sorbed to these silicate gangue minerals or associated with thin coatings of phyllosilicates or oxyhydroxides. In addition, As-bearing Fe oxides (lepidocrocite $(\gamma$-FeOOH), goethite $(\alpha-$ FeOOH), akaganéite ( $\beta-\mathrm{FeOOH})$ ), mixtures of Fe and Mn oxides, and tooeleite $\left(\mathrm{Fe}_{6}\left(\mathrm{AsO}_{3}\right)_{4}\left(\mathrm{SO}_{4}\right)(\mathrm{OH})_{4} \cdot 4 \mathrm{H}_{2} \mathrm{O}\right)$ were identified.

In the deeper tailings of MGL5 $(67-71 \mathrm{~cm})$, individual grains of arsenopyrite, Asbearingpyrite, andan Fe-As-Co-Ni phasewere identified by SEM and $\mu$ XRD.These fine-grained tailings include a mixture of As-bearing Mn oxides (birnessite $\left((\mathrm{Na}, \mathrm{Ca})_{0.5}\left(\mathrm{Mn}^{4+}, \mathrm{Mn}^{3+}\right)_{2} \mathrm{O}_{4} \cdot 1.5 \mathrm{H}_{2} \mathrm{O}\right)$, jacobsite $\left(\mathrm{MnFe}_{2} \mathrm{O}_{4}\right)$ and the Mnarsenite carbonate, armangite $\left(\mathrm{Mn}_{26} \mathrm{As}_{18} \mathrm{O}_{50}(\mathrm{OH})_{4}\left(\mathrm{CO}_{3}\right)\right)$. Muscovite with sorbedAs was also identified by $\mu \mathrm{XRF}$ and $\mu \mathrm{XRD}$. Framboidal pyrite was once again observed but was not found to contain As. The original arsenopyrite and As-bearing pyrite grains show a similar pattern to the nearsurface grains in that arsenopyrite shows a greater degree of weathering and replacement features.

\subsubsection{Goldenville tailings}

The near-surface high Ca tailings sample at GVL7 $(19-23 \mathrm{~cm})$ containsMn-Fe coatings on silicate grains, As-bearing Fe oxides, Fe-Ca-As replacement features, and Fe-Cr-Mn and FeCr-Bi grains. Distinct As- and Mn-bearing clusters were targeted in synchrotron analyses and 
found to be comprised ofmuscovite, vermiculite, and armangite (Fig. 5). Other areas of these tailings show no distinct primary or secondary As minerals but XRF element maps suggest As is sorbed to gangue minerals. At depth $(69-73 \mathrm{~cm})$, ESEM analyses show abundant sulfides, including arsenopyrite and As-bearing pyrite. Non-arsenian pyrite also occurs as single, weathered primary grains and arsenopyrite borders the edges of vegetation. Arsenic-bearing lepidocrociteand jacobsite were identified by $\mu \mathrm{XRD}$ and as well asAssorbed on muscovite, clinochlore, andillite (Fig. 5).

Subsurface tailings from GVL8 $(48-52 \mathrm{~cm})$ show an Fe-rich precipitate around silicate grains and As-bearing phases include As-sulfide, an As-bearing Fe-S phase around silicates (Fig. 4d), and arsenopyrite within organic remnants. Synchrotron targets here were identified as a mix of lepidocrocite, akaganéite, and birnessite (Fig. 6a,b,c). Other areas of distinct secondary precipitation consist of As-bearing lepidocrocite and akaganéite, and a mixture of lepidocrocite, realgar, greigite $\left(\mathrm{Fe}_{3} \mathrm{~S}_{4}\right)$, and fougèrite $\left(\mathrm{Fe}^{2+}{ }_{4} \mathrm{Fe}^{3+}{ }_{2}(\mathrm{OH})_{12}\left(\mathrm{CO}_{3}\right) \cdot 3 \mathrm{H}_{2} \mathrm{O}\right)$ (Fig. 7a,b,c). In some areas only muscovite, clinochlore, and anorthite were identified from As hotspots. Deeper tailings (67 $-71 \mathrm{~cm}$ and $99-103 \mathrm{~cm}$ ) show clusters of an As-S phase that appear to be secondary based on their delicate, wispy morphology (Fig. 4e). Arsenic-sulfide also occurs within plant structures (Fig. 4f) and around the edges of organic matter. Organic matter observedpetrographically correlates with As in $\mu$ XRF maps, suggesting organic-hosted As. Phases identified via $\mu$ XRFand $\mu \mathrm{XRD}$ include realgar, mackinawite $(\mathrm{FeS})$, and fougèrite \pm greigite, siderite $\left(\mathrm{FeCO}_{3}\right)$, and gypsum $\left(\mathrm{CaSO}_{4} \cdot 2 \mathrm{H}_{2} \mathrm{O}\right)($ Fig. 7 d,e,f).

Analysis by ESEM of GVL9 tailings from 35-39 $\mathrm{cm}$ depth shows arsenianpyrite and arsenopyrite are interspersed among silicate grains. Other phases include individual secondary grains of Fe-Ca-Mn with minor As, and arsenopyrite in plant material (Fig. 4g,h). Realgar, 
goethite ( \pm tooeleite) (Fig. 6d,e,f), mackinawite, and greigite, were identified by $\mu$ XRD. Arsenicsorbed gangue minerals include muscovite, clinochlore, illite, montmorillonite, phlogopite, and quartz.

\subsection{Pore water chemistry}

\subsubsection{Field parameters}

Average field parameters (temperature, $\mathrm{pH}$, Eh, specific conductance, dissolved oxygen, and alkalinity) for tailings pore waters are given in Table S3 (Supplementary Material). Each pore water sample is associated with one of the tailings types, and some are associated with organic matter underlying the tailings. Considering all samples, the lowest vadose zone $\mathrm{pH}$ value $(\mathrm{pH}$ 2.14) is from water associated with near-surface hardpan and the highest $(\mathrm{pH} 7.57)$ is from water associated with the near-surface high Ca tailings type. For saturated zone waters (i.e. from subsurface tailings and organic matter), $\mathrm{pH}$ ranges from 6.23 to 8.66 .

Measured Eh in vadose zone waters ranges from $113 \mathrm{mV}$ (oxictailings GV09-L8VZ) to nearly $700 \mathrm{mV}$ from hardpan vadose zone samples. Therelatively low Eh value from sample location GVL8, at only $18 \mathrm{~cm}$ depth, likely reflects the presence of decaying organic matter, frequent water table fluctuations, and periodic submergence, which would allow for reducing conditions to develop. Typical water table depth in this part of the tailings during the summer months is 45 masl, which means water table fluctuations of $20 \mathrm{~cm}$ are possible. This corresponds to the oxidized-reduced tailings boundary layer (DeSisto, 2014). Within the saturated zone, Eh ranges from $130 \mathrm{mV}$ to $347 \mathrm{mV}$. Highest DO is in waters from oxic and hardpan tailings (6-8 $\mathrm{mg} / \mathrm{L})$ but lower values $(1-4 \mathrm{mg} / \mathrm{L})$ are associated with multiple tailings types. There is a moderate correlation between Eh and DO, so either of these parameters could be used in qualitatively discussing the relative redox conditions of these waters. However, it is doubtful that 
As or Fe redox couples are in equilibrium with the Eh measured using a platinum electrode since redox disequilibrium is common in natural groundwaters (Lindberg \& Runnels, 1984), and the measured potential represents a mixed potential. Comparison of measured Eh values and calculated Eh values for the Fe, As, and S redox couples shows the Fe redox couple gives Eh values most similar to measured Eh values (DeSisto, 2014). This is expected as dissolved Fe concentrations are very high.

Specific conductance ranges from 136 to $2784 \mu \mathrm{S} / \mathrm{cm}$. Higher values generally occur in waters associated with high $\mathrm{Ca}$ and hardpan type tailings and lower values are from waters in the subsurface. Alkalinity from all waters ranges from below detection in hardpan-associated waters to $280 \mathrm{mg} / \mathrm{L} \mathrm{CaCO}_{3}$ in waters from high $\mathrm{Ca}$ vadose zone tailings and subsurface saturated zone tailings.

\subsubsection{Dissolved metals and speciation}

Total dissolved As from vadose zone pore waters ranges from less than detection $(<0.03$ $\mathrm{mg} / \mathrm{L}$ ) to $122 \mathrm{mg} / \mathrm{L}$ (median $7.92 \mathrm{mg} / \mathrm{L}$ ) and from saturated zone waters, $<0.03 \mathrm{mg} / \mathrm{L}$ to 45.1 mg/L (median $0.62 \mathrm{mg} / \mathrm{L}$ ) (Table S3, Supplementary Material). Dissolved Ca is highest in both vadose zone and saturated zone waters (492 and $298 \mathrm{mg} / \mathrm{L}$, respectively) from the high Ca tailings at Goldenville (GV-Location 7). Lowest Ca concentrations are from oxic (median 21.4 $\mathrm{mg} / \mathrm{L}$ ) and hardpan (median $15.1 \mathrm{mg} / \mathrm{L}$ ) tailings vadose zone waters. Highest dissolved total Fe in the vadose zone $(97.1 \mathrm{mg} / \mathrm{L})$ is associated with hardpan tailings (median $35.7 \mathrm{mg} / \mathrm{L} \mathrm{Fe}$ ), and in subsurface tailings pore waters the maximum total dissolved Fe is $129 \mathrm{mg} / \mathrm{L}$ (median $5.70 \mathrm{mg} / \mathrm{L}$ Fe). In hardpan areas, these very high dissolved Fe concentrations may be due to low $\mathrm{pH}$ conditions keeping Fe in solution (Fig. 8). In the subsurface, the high dissolved Fe may be due to mildly reducing conditions (Fig. 9). Lowest Fe concentrations are below detection $(<0.05 \mathrm{mg} / \mathrm{L})$ 
within both vadose zone and saturated zone waters. Sulfate is highest from both vadose zone $(1380 \mathrm{mg} / \mathrm{L}$; median $60.5 \mathrm{mg} / \mathrm{L})$ and saturated zone $(1190 \mathrm{mg} / \mathrm{L} ;$ median $65.2 \mathrm{mg} / \mathrm{L})$ waters at Goldenville, Location 7, the highest dissolved Ca location.

\subsubsection{Tailings types: Pore water comparison}

The metal concentrations and $\mathrm{pH}$ of pore waters from each tailings type are compared in Fig. 8. To add to this data set, waters collected in 2007 from Montague (DeSisto et al., 2011) are included in these figures and associated with the hardpan tailings type. Waters associated with hardpan tailings show elevated $\mathrm{As}, \mathrm{Fe}$, and $\mathrm{SO}_{4}{ }^{2-}$ concentrations, relatively low $\mathrm{Ca}$ concentrations, and the lowest $\mathrm{pH}$ values. Pore waters from the near-surface high $\mathrm{Ca}$ tailings and all the subsurface tailings show circumneutral $\mathrm{pH}$ values. Oxic tailings vadose zone samples have a widespread $\mathrm{pH}$ range from lower $\mathrm{pH}$ values, similar to hardpan pore waters, to higher $\mathrm{pH}$ values, similar to saturated zone waters. Within the circumneutral $\mathrm{pH}$ samples, dissolved As, Fe, and $\mathrm{SO}_{4}{ }^{2-}$ concentrations are wide-ranging. Generally, waters associated with the high $\mathrm{Ca}$ tailings have some of the highest $\mathrm{Ca}$ concentrations. The consistently high $\mathrm{pH}$ of the subsurface waters suggests the original carbonate minerals may still be present below the zone of sulfide oxidation. A similar set of comparisons is made for dissolved element concentrations and Eh in Fig. 9. Pore waters associated with hardpan have the most oxidizing values (500 to $700 \mathrm{mV}$ ) and high total dissolvedAs and $\mathrm{Fe}$ concentrations.Highest $\mathrm{Ca}$ concentrations are from high $\mathrm{Ca}$ and oxic tailings type pore waters that also have relatively lower Eh values (100 to $500 \mathrm{mV}$ ). Conversely, the lower Ca, higher Eh waters are associated with hardpan tailings. There appears to be a continuum of water chemistry concerning the $\mathrm{SO}_{4}{ }^{2-}-$ Eh relationship. Oxic tailings and hardpan pore waters have high $\mathrm{SO}_{4}{ }^{2-}$ concentrations and higher Eh values whereas high $\mathrm{Ca}$ and saturated 
zone samples generally have high $\mathrm{SO}_{4}{ }^{2-}$, but lower Eh values (Fig. 9), reflecting the degree of sulfide oxidation in the tailings.

\section{Discussion}

\subsection{Subsurface arsenic mineral hosts}

The first objective of this study was to determine if the As hosts are alike in all subsurface tailings, or if the composition of these tailings reflect the varied tailings types identified at surface. Our original assumption was that the wetland tailings should contain most of their As in arsenopyrite and generally be representative of the deeper tailings underlying all other tailings types. However, mineralogical analysis of these tailings shows they are diverse spatially at surface among the four tailings types (i.e. hardpan, oxic, high $\mathrm{Ca}$, and wetland type

tailings) and are also variable with depth. The main As-bearing phases identified at depth, or in reducing conditions near surface, are summarized in Table 2. Table S4 (Supplementary Material) summarizes the mineral occurrences and the associated water and bulk chemistry with depth at the five locations that were the focus of this mineralogical work. Pore water chemistry from these locations indicates all subsurface pore waters are circumneutral. All Eh values are above $+100 \mathrm{mV}$, indicating none of the bulk pore waters are truly anoxic but are either oxidizing (Montague Locations 2 and 5) or moderately reducing (Goldenville Locations 7, 8, and 9). Variations in Eh do not clearly relate to depth and may instead be related to a combination of hydrogeological characteristics and locally abundant organic matter (DeSisto, 2014).

\subsection{Geochemical controls on arsenic mineral mobility}

The second objective of this work was to identify present-day geochemical controls on As mobility in the gold mine tailings at Montague and Goldenville. Based on the results reported 
here and in DeSisto et al. (2011), we conclude that under more oxidizing conditions, the dissolved As concentrations in tailings pore waters are controlled by:

1) Oxidative dissolution of primary arsenopyriteand As-bearing pyrite

2) Precipitation of secondary $\mathrm{Fe}$ arsenates (e.g. scorodite, amorphous $\mathrm{Fe}$ arsenate) and the arsenite sulfate mineral tooeleite

3) Precipitation of secondary Fe oxyhydroxides and Mn oxides (e.g. akaganéite, lepidocrocite, goethite, birnessite, jacobsite)

4) Precipitation of secondary $\mathrm{Ca}(\mathrm{Fe})$ arsenates (e.g. yukonite)

5) Sorption onto Fe oxyhydroxides

6) Sorption onto gangue minerals (e.g. muscovite, quartz, clinochlore, illite, albite)

The $\mathrm{Fe}$ - and $\mathrm{Ca}(\mathrm{Fe})$-arsenates (scorodite, yukonite) and the arsenite (tooeleite) identified in these tailings are significant for their high As contents (25 - 33 wt. \%) and their association together suggests the importance of chemical microenvironments. Scorodite and tooeleite both require acidic conditions to precipitate (Nishimura \& Robins, 2008) but were identified in locations where the bulk pore water exhibited circumneutral $\mathrm{pH}$. It is probable that sulfide oxidation within the tailings is creating acidic microenvironments conducive to scorodite and tooeleite precipitation (DeSisto et al. 2011). Scorodite has also been identified from the same thin section as yukonite, which precipitates under neutral to alkaline conditions.In addition to the likelihood of microenvironments, it is possible for $\mathrm{Ca}-\mathrm{Fe}$ arsenates to precipitate over time concurrently with sulfide consumption and increasing $\mathrm{pH}$. Under such conditions, scorodite and other $\mathrm{Fe}(\mathrm{III})$ arsenates become unstable and can convert to $\mathrm{Ca}-\mathrm{Fe}$ arsenates (Paktunc et al., 2003, 2004; Jia\& Demopoulos, 2008; Bluteau et al., 2009; Surour et al., 2013).Redox 
microenvironments also exist as tooeleite, an arsenite, was identified in the same sample along with Fe oxides and pyrite.

Under oxidizing conditions and increasing $\mathrm{pH}, \mathrm{Fe}(\mathrm{III})$ and $\mathrm{Mn}(\mathrm{IV})$ will precipitate to form their respective oxides. Iron oxides such as lepidocrocite, akaganéite, and goethite are identified at all sample locations and generally persist with depth except at Montague Locations 2 and 5.Saturation index (SI) calculations show goethite and lepidocrocite to have SI values $>1$ from all pore waters (Table 3), further supporting their stability. Manganese occurs in bulk tailings (Table S4, Supplementary Material) and was detected by micro-XRF (Fig. 5, 6) but SI calculations show the Mn oxides birnessite, manganite, and hausmanniteto be unsaturated. However, birnessite and jacobsite were identified in Goldenville Location 7 and 8 tailings. The adsorption or coprecipitation of dissolved As on Fe and Mn oxides has been well demonstrated (e.g. Bose \& Sharma, 2002; Manning et al. 2002; Deschamps et al. 2003; Ying et al. 2012). These Mn phases may not be stable with depth at Goldenville Location 7, where pore waters are more reducing, as dissolved $\mathrm{Mn}$ concentrations are relatively high and bulk concentrations are moderate (Table S4, Supplementary Material). Within these Nova Scotia tailings, the Mn oxides are less abundant than Fe oxides and may represent a less stable source of attenuated As.

At depth, the more reducing environment is unfavorable for $\mathrm{Fe}$ - and $\mathrm{Ca}-\mathrm{Fe}$ arsenates but is amenable to sulfide stability, including the persistence of primary arsenopyrite and the precipitation of secondary sulfide minerals. The results of this study suggest that dissolved As concentrations in the subsurface tailings pore waters are primarily controlled by:

1) Dissolution of Fe oxides (goethite, lepidocrocite, akaganéite) and Mn oxides(jacobsite, birnessite)

2) Precipitation of authigenicAs and Fe sulfides (greigite, mackinawite, realgar) 
3) Sorption onto carbonates (fougèrite, armangite, siderite)

4) Precipitation onto sulfates (gypsum, tooeleite)

5) Coprecipitation with the above phases

Under suboxic to anoxic conditions, Fe and Mn oxides may experience reductive dissolution with subsequent release of any sorbedAs to local waters. Some studies have shown that transformation of Fe oxides under reducing conditions allows for the precipitation of metastable, intermediate Fe(II) or mixed Fe(II, III) phases, such as siderite or fougèrite, the mineral analogue to green rust. These intermediate phases have been found to sorb dissolved As (O’Day et al., 2004; Kocar et al. 2006, Jönsson\& Sherman 2008; Ona-Nguema et al. 2009). Arsenic concentrations in pore water significantly decrease with depth in these tailings, due in part to sorption onto Fe andMn oxides, siderite, and fougèrite. For Goldenville tailings, mackinawite and siderite SI values are within \pm 1 and greigite and green rust (i.e. fougèrite) SI values indicate supersaturation (Table 3). The presence of reduced Fe phases such as siderite and/or fougèritein the Goldenville samples along with oxidized Fe(III) oxides suggests that if $\mathrm{Fe}$ oxides are undergoing reductive dissolution, it is a slow and incomplete process.

Arsenic concentrations are also limited by association with sulfates such as gypsum. This may be happening via surface sorption processes or through substitution of arsenic for sulfate within the mineral structure (Lin et al., 2013). This is alsopossibleforjarosite (Paktunc\&Dutrizac, 2003), but this phase was not identified in the tailings or predicted to form based on SI calculations.Sulfate and calcium concentrations are high at Goldenville Location 8 (Table S3, Supplementary Material) where gypsum was identified in subsurface tailings (Fig. 7). Saturation index calculations predict gypsum equilibrium ( $\mathrm{SI} \pm 1$ ) for these tailings, as well as for Goldenville Location 7 tailings (Table 3), meaning gypsum may only be a temporary host for As. 
Another mechanism leading to decreased As concentrations with depth is the precipitation of realgar. Realgar has been found forming on pyrite surfaces in shallow aquifer sediments (O’Day et al. 2004) and a single occurrence of realgar has been previously identified in the Nova Scotia wetland-type tailings at Montague (Walker et al. 2009). O'Day et al. (2004) found that where dissolved As concentrations reached micromolar levels, realgar could precipitate under near-surface low-temperature conditions. Where realgar occurs in the Goldenville tailings (Locations 8 and 9), dissolved As concentrations are well above this condition having concentrations of As in the 100 to $1000 \mu \mathrm{M}$ range.

The deepest tailings at Goldenville and Montague are in direct contact with organic matter, which represents the remains of wetland vegetation that was covered by the tailings. Over time and due to burial, the vegetation decomposed and generated a more reducing environment. In these deepest tailings framboidal pyrite is observed. The formation and size of the framboids are related to redox conditions (Wilkin et al., 1996; Wilkin \& Barnes, 1997) because dissolved Fe and sulfide must be present. The occurrence here fits with these conditions as $\mathrm{SO}_{4}$-reducing bacteria are likely producing enough sulfide through degradation of the organic matter and dissolved $\mathrm{SO}_{4}{ }^{2-}$ to reach supersaturated conditions for pyrite precipitation. The framboids provide clear evidence of reducing, sulfidic conditions. Although As was not found within the framboids analyzed, it is a viable host of As in the deeper tailings. The results of this study cannot distinguish between framboids forming under current geochemical conditions in the tailings and those that may have formed in the wetland prior to tailings deposition. Thread-like mineral textures (e.g. Fig. 4) and grain or plant material coatings with sulfide compositions fitting realgar, mackinawite, and greigite in these tailingsprovide evidence that secondary sulfide precipitation is occurring. The Fe monosulfidesmackinawite and greigite are known as 
intermediate phases to pyrite formation in low-temperature environments (Rickard \& Luther, 2006) where the sequence of formation proceeds as: amorphous FeS $\rightarrow$ mackinawite $\rightarrow$ greigite $\rightarrow$ pyrite (Lennie \& Vaughan, 1996). Previous work has found individual grains of primary pyrite in these tailings to contain up to $3 \mathrm{wt.} \%$ As (DeSisto et al., 2011). These intermediate phases are highly reactive (Rosso \& Vaughan, 2006) and many studies have identified the occurrence of As with mackinawite or greigite (e.g. Sracek et al., 2004; Wilkin \& Ford 2006). Farquar et al. (2002) and Wolthers et al. $(2003,2005)$ found dissolved As forms outer sphere complexes with the mackinawite surface and Bostick\&Fendorf (2003) concluded As sorption on Fe sulfide surfaces may be an effective way of regulating dissolved As concentrations in reducing environments. However, they further state that oxidation may lead to a release of As from the sulfide surfaces in a process similar to the release of As during reductive dissolution of Fe oxides. This has implications for future management of the historical Nova Scotia tailings. Reprocessing of tailings to recover additional gold would bring these sulfide phases to surface and expose them to more oxidizing conditions. Iron and Mn oxides would be more stable in such conditions, but these secondary sulfides would be easily oxidized and any sorbed or coprecipitatedAs would be released. Precipitated Fe or Mn oxides could potentially sorb some of this dissolved As, but sorption sites would have to exceed the quantity of dissolved As to limit the mobility of As. In addition, oxidation of these sulfides might lead to acidic conditions, dissolving oxides and carbonates of $\mathrm{Fe}$ and $\mathrm{Mn}$.

\subsection{Identifying tailings types: Application to other sites}

The use of synchrotron-based methods, especially $\mu \mathrm{XRD}$, has been essential to the identification of many of the mineral phases within these tailings. However, this may not be an ideal approach for other instances where distinguishing the tailings types may be necessary. A 
practical goal of this work was to determine whether the different tailings types, including subsurface tailings, can be identified via less-specialized methods while still capturing the detail and range in As host mineralogy that will be important to inform remediation decisions. To test this, the tailings bulk chemistry and theoretical composition of minerals identified through $\mu$ XRD were plotted on ternary diagrams (Fig. 10). The data in Fig. 10 suggest it would be difficult to identify the tailings types found in historical gold mine tailings from either bulk chemistry or from $\mu \mathrm{XRD}$ alone. Only for the hardpan tailings can bulk chemistry be used to distinguish these tailings from the other tailings types as the bulk chemistry clearly aligns with the minerals known to occur in the hardpan (scorodite, arsenopyrite, tooeleite). The bulk chemistry of the other tailings types does not correlate as well to the known mineralogy within the tailings, reflecting the lower total As content of these end members. This shows the important role that $\mu \mathrm{XRD}$ has as a tool for supporting remediation decisions.

\section{Conclusions}

Previous studies of historical gold mine tailings in Nova Scotia have identified four main types of near-surface tailings (hardpan-bearing, oxic, high $\mathrm{Ca}$, and wetland type tailings) based on their visual characteristics, their distinct As-bearing phases, and their abundance. Future remediation efforts will have to deal with all four of these end members, as well as the underlying subsurface tailings. The aim of the present work was to characterize the As hosts in these subsurface tailings and to assess the present-day geochemical controls on As mobility within these tailings. Bulk chemistry, ESEM, and synchrotron-based $\mu$ XRDand $\mu$ XRF analyses were used to distinguish the mineralogical composition of the tailings. This was correlated with results from pore water chemistry. It was found that: 
1) The As-bearing phases in all subsurface tailings are not alike and instead comprise variable combinations of primary sulfides (arsenopyrite, pyrite), secondary sulfides (realgar, mackinawite, greigite), carbonates (siderite, fougèrite), Fe oxides (goethite, akaganéite, lepidocrocite), Mn oxides (birnessite, jacobsite), and sulfates (tooeleite, gypsum).

2) All pore water Eh values are above $+100 \mathrm{mV}$, indicating that pore waters are either oxic or mildly reducing. Spatialvariations appear to be related to the presence or absence of organic matter.

3) Under oxidizing conditions dissolved As concentrations are controlled by

- Oxidative dissolution of primary arsenopyriteand arsenian pyrite;

- Precipitation of secondary Fe arsenates, secondary Fe oxyhydroxides and Mn oxides, secondary Ca-Fe arsenates; and,

- Sorption onto Fe oxyhydroxides and gangue minerals.

4) Under reducing conditions dissolved As concentrations are controlled by

- Dissolution of Fe and Mn(oxyhydrox)oxides;

- Precipitation of authigenicAs and Fe sulfides and of sulfates; and,

- Sorption or co-precipitation with carbonates.

These results have implications for future site management because reprocessing of the tailings to recover additional gold or excavation of the tailings as a remediation option would bring sulfide phases to surface and expose them to oxidizing conditions. This would also produce acidic conditions, dissolving As-sorbed Fe and Mn oxides and carbonates. A logical remediation choice at these publicly accessible sites would be to cover the tailings. However, the variable tailings mineralogy and spatially close association of these geochemically heterogeneous 
minerals means at least some of these As-bearing phases may become unstable if reducing conditions develop under a cover, potentially exacerbating the release of As to the local environment.

\section{Acknowledgements}

The authors thank two anonymous reviewers and Jeanne Percivalfor their comments on this manuscript. We appreciate field assistance from Ryan Brunt and Heather Sealey and analytical assistance from Mary Andrews, Graham Cairns (ASU, Queen's University), Jacqueline London (Trent University), and Bill LeBlanc (GSC-Atlantic). Steve Walker is thanked for helpful insights on initial XRD interpretations. This project was initially made possible through financial support from the NSERC Metals in the Human Environment Strategic Network (MITHE-SN) with subsequent funding by an NSERC Strategic Grant to Heather Jamieson, Michael Parsons, Dirk Wallschläger, Danielle Fortin, and Kerry Rowe. Partial funding for the study was also provided through the Environmental Geoscience Program (2009 - 2014) of the Earth Sciences Sector at Natural Resources Canada. Portions of this work were performed at Beamline X26A, National Synchrotron Light Source (NSLS), Brookhaven National Laboratory. X26A is supported by the Department of Energy (DOE) - Geosciences (DE-FG02-92ER14244 to The University of Chicago - CARS). Use of the NSLS was supported by DOE under Contract No. DE-AC02-98CH10886. This is contribution number 20150407 of the Earth Sciences Sector, Natural Resources Canada.

\section{References}

Ball, J.W., Nordstrom, D.K., 1991. WATEQ4F - User's manual with revised thermodynamic data base and test cases for calculating speciation of major, trace and redox elements in natural waters. U.S. Geological Survey Open-File Report 90-129, 185 p.

Bates, J.L.E., 1987. Gold in Nova Scotia. Nova Scotia Department of Natural Resources. Mineral Resources Branch, Information Series 13, 48 p. (available online at: http://www.gov.ns.ca/natr/meb/pdf/is13.asp).

Bluteau, M.-C., Becze, L., Demopoulos, G.P., 2009. The dissolution of scorodite in gypsumsaturated waters: Evidence of $\mathrm{Ca}-\mathrm{Fe}-\mathrm{AsO}_{4}$ mineral formation and its impact on arsenic retention. Hydrometallurgy, 97, 221-227.

Bose, P., Sharma, A., 2002. Role of iron in controlling speciation and mobilization of arsenic in subsurface environment. Water Res., 36, 4916 - 4926. 
Bostick, B. C., Fendorf, S., 2003. Arsenite sorption on troilite (FeS) and pyrite $\left(\mathrm{FeS}_{2}\right)$. Geochim. et Cosmochim. Acta, 67, 909-921.

Bowell, R.J., Craw, D., 2014. The management of arsenic in the mining industry. In: Bowell, R.J., Alpers, C.N., Jamieson, H.E., Nordstrom, D.K., Majzlan, J. Arsenic: Environmental Geochemistry, Mineralogy, and Microbiology. Reviews in Mineralogy and Geochemistry, 79, pp. 507-532.

Corriveau, M.C., Jamieson, H.E., Parsons, M.B., Campbell, J.L., Lanzirotti, A., 2011a. Direct characterization of airborne particles associated with arsenic-rich mine tailings: Particle size, mineralogy and texture. Appl. Geochem., 26, 1639-1648.

Corriveau, M.C., Jamieson, H.E., Parsons, M.B., Hall, G.E.M., 2011b. Mineralogical characterization of arsenic in gold mine tailings from three sites in Nova Scotia.

Geochem.Explor., Environ., Anal., 11, 179-192.

Desbarats, A.J., Parsons, M.B., Percival, J.B., Beauchemin, S., Kwong, Y.T.J., 2011.Geochemistry of mine waters draining a low-sulfide, gold-quartz vein deposit, Bralorne, British Columbia. Appl. Geochem.,26, 1990-2003.

Deschamps, E., Ciminelli, V.S.T., Weidler, P.G., Ramos, A.Y., 2003. Arsenic sorption onto soils enriched in Mn and Fe minerals. Clay Clay Miner., 51, 197-204.

DeSisto, S.L. 2014. Hydrogeochemical evaluation and impact of remediation design on arsenic mobility at historical gold mine sites. Ph.D. Thesis, Queen's University, Kingston, ON, 490 pp. (https://qspace.library.queensu.ca/handle/1974/12227)

DeSisto, S.L., Jamieson, H.E., Parsons, M.B., 2011. Influence of hardpan layers on arsenic mobility in historical gold mine tailings. Appl. Geochem., 26, 2004-2018.

Farquar M.L., Charnock, J.M., Livens, F.R., Vaughan, D.J., 2002. Mechanisms of arsenic uptake from aqueous solution by interaction with goethite, lepidocrocite, mackinawite, and pyrite: An X-ray absorption spectroscopy study. Environ. Sci. Technol., 36, 1757-1762.

García-Sanchez, A., Alvarez-Ayuso, E., Rodriguez-Martin, F., 2002. Sorption of As (V) by some oxyhydroxides and clay minerals. Application to its immobilization in two polluted mining soils. Clay Miner., 37, 187-194.

Goldberg, S., 2002. Competitive adsorption of arsenate and arsenite on oxides and clay minerals. Soil Sci. Soc. Am. J., 66, 413-421.

Groves, D., Goldfarb, R., Gebre-Mariam, M., Hagemann, S., Robert, F. 1998. Orogenic gold deposits: A proposed classification in the context of their crustal distribution and relationship to other gold deposit types. Ore Geol. Rev. 13, 7-27. 
Haffert, L., Craw, D., Pope, J., 2010. Climatic and compositional controls on secondary arsenic mineral formation in high-arsenic mine wastes, South Island, New Zealand. New ZealandJ. Geol. Geophys.,53, 91-101.

Hammersley, A.P.,1998.Fit2D V 10.3, Reference Manual V 4.0. European Synchrotron Research Facility, Paper ESRF98-HA01T(program and manual available athttp://www.esrf.eu/computing/scientific/FIT2D/).

Hashimoto, K., Misawa, T., 1973. The solubility of $\gamma$-FeOOH in perchloric acid. Corr. Sci., 13, 229-231.

Hennick, E., Poole, J., 2013. Nova Scotia Abandoned Mine Openings Database, Version 5, 2013. Nova Scotia Department of Natural Resources, Digital Product DP ME 10. Available online at: http://www.novascotia.ca/natr/meb/links/amolinks.asp.

ICDD, 2003. Powder Diffraction File (PDF 2), Release 2003. International Centre for Diffraction Data, Newtown Square, Pennsylvania.

Jamieson, H.E., 2011. Geochemistry and mineralogy of solid mine waste: essential knowledge for predicting environmental impact. Elements, 7, 381-386.

Jamieson, H.E., Walker, S.R., Parsons, M.B., 2015. Mineralogical characterization of mine waste. Appl. Geochem., 57, 85-105.

Jia, Y., Demopoulos, G.P., 2008.Coprecipitation of arsenate with iron (III) in aqueous sulfate media: effect of time, lime as base and co-ions on arsenic retention. Water Res., 42, 661-668.

Jönsson, J., Sherman, D. M., 2008. Sorption of As(III) and As(V) to siderite, green rust (fougerite) and magnetite: Implications for arsenic release in anoxic groundwaters. Chem. Geol, $255,173-181$.

Kavalench, J.L., 2010. Effect of tailings mineralogy and infiltration water chemistry on arsenic release from historic gold mine tailings. M.Sc. Thesis, Queen's University, Kingston, ON, 227 pp.

Kocar, B.D., Herbel, M.J., Tufano, K.J., Fendorf, S., 2006. Contrasting effects of dissimilatory iron(III) and arsenic(V) reduction on arsenic retention and transport. Environ. Sci. Technol., 40, $6715-6721$.

Kontak, D.K., Smith, P.K., 1988. Meguma gold studies IV: Chemistry of vein mineralogy. In: Report of Activities 1987 Part B: Nova Scotia Department of Mines and Energy, Mines and Minerals Branch, Report 88-1, pp. 85-101.

Kwong, Y.T.J., Beauchemin, S., Hossain, M.F., Gould, W.D., 2007. Transformation and mobilization of arsenic in the historic Cobalt mining camp, Ontario, Canada. J.

Geochem.Explor., 92, 133-150. 
Lennie, A.R., Vaughan, D.J., 1996. Spectroscopic studies of iron sulfide formation and phase relations at low temperatures. Mineral Spectroscopy: Special Publication, No. 5, 117-131.

Lin, Z., Puls, R.W., 2000. Adsorption, desorption and oxidation of arsenic affected by clay minerals and aging process. Environ. Geol., 39, 753-759.

Lin, J., Chen, N., Nilges, M.J., Pan, Y., 2013. Arsenic speciation in synthetic gypsum (CaSO4-2H2O): a synchrotron XAS, single-crystal EPR, and pulsed ENDOR study. Geochim. Cosmochim. Acta, 106, 524-540.

Lindberg, R.D., Runnels, D.D., 1984. Ground water redox reactions: An analysis of equilibrium state applied to Eh measurements and geochemical modeling. Science, 225, 925-927.

Lindsay, M.B.J., Blowes, D.W., Condon, P.D., Ptacek, C.J., 2009. Managing pore-water quality in mine tailings by inducing microbial sulfate reduction. Environ. Sci. Technol., 43, 7086-7091.

Lottermoser, B., 2010.Mine wastes: characterization, treatment and environmental impacts. $3^{\text {rd }}$ edition, Springer. $414 \mathrm{p}$.

Lynch, J., 1990. Provisional elemental values for eight new geochemical lake sediment and stream sediment reference materials: LKSD-1, LKSD-2, LKSD-3, LKSD-4, STSD-1, STSD-2, STSD-3 and STSD-4. Geostandards Newsletter, 14, 153-167.

Majzlan, J., Lalinská, B., Chovan, M., Bläß, U., Brecht, B., Göttlicher, J., Steininger, R., Hug, K., Ziegler, S.,Gescher, J., 2011. A mineralogical, geochemical, and microbiological assessment of the antimony-and arsenic-rich neutral mine drainage tailings near Pezinok, Slovakia. Am. Mineral., 96, 1-13.

Manning, B.A., Fendorf, S., Bostick, B., Suarez, D.L., 2002. Arsenic(III) oxidation and arsenic(V) adsorption reactions on synthetic birnessite. Environ. Sci. Technol., 36, 976 - 981.

MEND, 2004. Review of water quality issues in neutral pH drainage: Examples and emerging priorities for the mining industry in Canada. MEND Report 10.1.

Meunier, L., Walker, S.R., Wragg, J., Parsons, M.B., Koch, I., Jamieson, H.E., Reimer, K.J. 2010.Effects of soil composition and mineralogy on the bioaccessibility of arsenic fromtailings and soil in gold mine districts of Nova Scotia. Environ.Sci.Technol., 44, 2667-2674.

Nishimura, T., Robins, R.G., 2008.Confirmation that tooeleite is a ferric arsenite sulfate hydrate, and is relevant to arsenic stabilisation. Miner. Eng., 21, 246-251.

Nordstrom, D.K., 2011. Mine waters: Acidic to circumneutral. Elements, 7, 393-398.

Nova Scotia Department of Natural Resources, 2002. Mineral Resource Land-Use (MRLU) Maps, Nova Scotia, Version 2, 2002. Compiled by D.B. Hopper, F.J. Bonner, B.E. Fisher and 
A.N. Murphy, scale 1:50 000. Open File Maps ME 2000-4. Available online at: http://www.novascotia.ca/natr/meb/download/dp047.asp.

O’Day, P., Vlassopoulos, D., Root, R., Rivera, N., Karl, K., 2004. The influence of sulfur and iron on dissolved arsenic concentrations in the shallow subsurface under changing redox conditions. Proc. Natl. Acad. Sci. U.S.A., 101, 13703-13708.

Ona-Nguema, G., Morin, G., Wang, Y., Menguy, N., Juillot, F., Olivi, L., Aquilanti, G., Abdelmoula, M., Ruby, C., Bargar, J.R., Guyot, F., Calas, G., Brown, G.E., Jr.,2009. Arsenite sequestration at the surface of nano- $\mathrm{Fe}(\mathrm{OH})_{2}$, ferrous-carbonate hydroxide, and green-rust after bioreduction of arsenic-sorbed lepidocrocite by Shewanellaputrefaciens.

Geochim.Cosmochim.Acta, 73, 1359-1381.

Paktunc, D., Dutrizak, 2003. Characterization of arsenate-for-sulfate substitution in synthetic jarosite using X-ray diffraction and X-ray absorption spectroscopy. Can. Mineral., 41, 905-919.

Paktunc, D., Foster, A., Laflamme, G., 2003. Speciation and characterization of arsenic in Ketza River mine tailings using X-ray absorption spectroscopy. Environ. Sci. Technol., 37, 2067-2074.

Paktunc, D., Foster, A., Heald, S., Laflamme, G., 2004. Speciation and characterization of arsenic in gold ores and cyanidation tailings using X-ray absorption spectroscopy. Geochim.Cosmochim.Acta, 68, 969-983.

Parkhurst, D.L., Appelo, C.A.J., 2013. Description of input and examples for PHREEQC version 3 - A computer program for speciation, batch-reaction, one-dimensional transport, and inverse geochemical calculations: U.S. Geological Survey Techniques and Methods, book 6, chap. A43, 497 p., available online at http://pubs.usgs.gov/tm/06/a43/.

Parsons, M.B., LeBlanc, K.W.G., Hall, G.E.M., Sangster, A.L., Vaive, J.E., Pelchat, P., 2012. Environmental geochemistry of tailings, sediments and surface waters collected from 14 historical gold mining districts in Nova Scotia; Geological Survey of Canada, Open File 7150. doi:10.4095/291923.

Percival, J.B., White, H.P., Goodwin, T.A., Parsons, M.B., Smith, P.K., 2013. Mineralogy and spectral reflectance of soils and tailings from historical gold mines, Nova Scotia.

Geochem.Explor., Environ., Anal., 14, 3-16.

Planer-Friedrich, B., London, J., McCleskey, R.B., Nordstrom, D.K., Wallschläger, D., 2007.Thioarsenates in geothermal waters of Yellowstone National Park: determination, preservation, and geochemical importance. Environ. Sci. Technol., 41, 5245-5251.

Rickard, D., Luther G.W. III, 2006. Metal Sulfide Complexes and Clusters. In: Rosso, J.J. (Ed.), Sulfide Mineralogy \& Geochemistry, Reviews in Mineralogy \& Geochemistry, Chapter 8, vol. 61, pp. 421-504. The Mineralogical Society of America, Chantilly, VA. 
Rickard, D., Luther G.W. III, 2007. Chemistry of iron sulfides. Chemical Reviews, 107, 514562.

Rosso K.M., Vaughan D.J., 2006. Reactivity of sulfide mineral surfaces. In: Rosso, J.J. (Ed.), Sulfide Mineralogy \& Geochemistry, Reviews in Mineralogy \&Geochemistry, Chapter 10, vol. 61, pp. 557-607. The Mineralogical Society of America, Chantilly, VA.

Ryan, R.J., Smith, P.K., 1998. A review of the mesothermal gold deposits of the Meguma Group, Nova Scotia, Canada. Ore Geol. Rev., 13, 153-183.

Savage, K.S., Tingle, T.N., O'Day, P.A., Waychunas, G.A., Bird, D.K., 2000. Arsenic speciation in pyrite and secondary weathering phases, Mother Lode Gold District, Tuolumne County, California. Appl. Geochem., 15, 1219-1244.

Saunders, J.R, Knopper, L.D., Koch, I., Reimer, K.J., 2011. Inclusion of soil arsenic bioaccessibility in ecological risk assessment and comparison with biological effects. Sci. Total Environ., 412-413, 132-137.

Scharer, J.M., Pettit, C.M., Kirkaldy, J.L., Bolduc, L.,Halbert, B.E., Chambers, D.B., 2000. Leaching of metals from sulphide mine wastes at neutral $\mathrm{pH}$.In:Proceedings of the 5thInternational Conference on Acid Rock Drainage (ICARD 2000). Denver, CO, pp. 21-24.

Seal, R.R., Hammarstrom, J.M., 2003. Chapter 2: Geoenvironmental models of mineral deposits: Examples from massive sulfide and gold deposits. In: Jambor, J.L., Blowes, D.W., Ritchie, A.I.M., (Eds.), Environmental Aspects of Mine Wastes. Short Course Series vol. 31, pp. 11-50. Vancouver, Mineralogical Association of Canada.

Sracek, O., Bhattacharya, P., Jacks, G., Gustafsson, J-P., von Brömssen, M., 2004. Behavior of arsenic and geochemical modeling of arsenic enrichment in aqueous environments. Appl.Geochem., 19, 169-180.

Surour, A.A., Ahmed, A.H., Harbi, H.M., 2013.Yukonite-like alteration products (Ca-Fe arsenate and As-rich Fe-oxyhydroxide) formed by in situ weathering in granodiorite, Bi'rTawilah gold prospect, Saudi Arabia. Eur. J. Mineral., 25, 61-70.

Walker, S.R., Jamieson, H.E., Lanzirotti, A., Andrade, C.F., Hall, G.E.M., 2005. The speciation of arsenic in iron oxides in mine wastes from the Giant Gold Mine, N.W.T.: application of synchrotron micro-XRD and micro-XANES at the grain scale. Can.Mineral., 43, 1205-1224.

Walker, S.R., Parsons, M.B., Jamieson, H.E., Lanzirotti, A., 2009. Arsenic mineralogy of nearsurface tailings and soils: influences on arsenic mobility and bioaccessibility in the Nova Scotia gold mining districts. Can. Mineral., 47, 533-556.

Wallschläger, D., Stadey, C.J., 2007. Determination of (oxy)thioarsenates in sulfidic waters. Anal. Chem., 79, 3873-3880. 
Wilkin, R.T., Barnes, H.L., Brantley, S.L., 1996. The size distribution of framboidal pyrite in modern sediments: An indicator of redox conditions. Geochim.Cosmochim.Acta, 60, 3897-3912.

Wilkin, R.T., Barnes, H.L., 1997. Formation processes of framboidal pyrite.

Geochim.Cosmochim.Acta, 61, 323-339.

Wilkin, R.T., Ford, R.G., 2006. Arsenic solid-phase partitioning in reducing sediments of a contaminated wetland. Chem. Geol., 228, 156-174.

Wolthers, M., Charlet, L., van der Weijden, C.H., 2003. Arsenic sorption onto disordered mackinawite as a control on the mobility of arsenic in the ambient sulphidic environment. J. Phys-Paris, 107, 1377-1380.

Wolthers, M., Charlet, L., Van Der Weijden, C.H., Van der Linde, P.R., Rickard, D., 2005. Arsenic mobility in the ambient sulfidic environment: Sorption of arsenic(V) and arsenic(III) onto disordered mackinawite. Geochim.Cosmochim.Acta, 69, 3483-3492.

Ying, S.C., Kocar, B.D., Fendorf, S., 2012. Oxidation and competitive retention of arsenic between iron- and manganese oxides. Geochim.Cosmochim.Acta, 96, 294-303. 
Table 1:Calculated correlation coefficients (r) and p-values for key components of the bulk tailings chemistry between near surface tailings types and subsurface tailings. Significant pvalues $(<0.05)$ are in bold. Sample locations refer to Montague $(\mathrm{MG})$ and Goldenville $(\mathrm{GV})$ (Figure 1).

Table 2:Summary of phases identified in subsurface and/or reduced near-surface tailings in which As is a major, minor, or trace constituent.

Table 3:Mineral saturation indices calculated in PHREEQC using vadose zone (VZ) and saturated zone (SZ) pore water chemistry.Dashed lines indicate a phase was not predicted in the output.

Figure 1: Sample locations in 2009 from (A) Montague Gold Mines tailings and (B) Goldenville tailings. Map data: mine shaft information (Hennick\& Poole, 2013), topographic data (Nova Scotia Department of Natural Resources, 2002).

Figure 2: Distribution of near-surface tailings types at (A) Montague and (B) Goldenville. Some high $\mathrm{Ca}$ tailings occur with depth in the Montague tailings, but generally do not occur at surface.

Figure 3: Representativebulk chemistry depth profiles from: (A) MGL3, hardpan near surface; (B) GVL3, oxic tailings near surface; and (C) GVL6, high-Ca tailings near surface. Open symbols indicate value is below the detection limit.

Figure 4: Representative backscattered electron images of As phases identified at depth. MGL5 (20-24 cm depth)(A) Fe-Ca-As secondary coating on silicate grains, (B) Fe-Mn-As secondary rim around a silicate, $(\mathrm{C})$ concentric growth pattern of an As-bearing Fe-Mn-Ca phase. GVL8 (48-52 cm depth) (D)As-bearing Fe-S cement around silicates. GVL8 (99-103 cm depth) (E)AsS phase with delicate morphology, (F)As-S phase within plant structure.GVL9 (35-39 cm depth) (G) Arsenopyrite, (H) Fe-Ca-Mn-As precipitate around silicate grains.

Figure 5:GVL7 (cm depth) (A) Petrographic image (TL/RL) of area targeted for synchrotron analyses, (B) Tricolor $\mu$ XRF map for As-Fe-Mn, (C) Example $\mu$ XRD results: gangue minerals muscovite and vermiculite with armangite. GVL7 (cm depth) (D) Petrographic image (TL/RL) of area targeted for synchrotron analyses, (E) Tricolor $\mu$ XRF maps for As-Fe-Ca and Mn-Fe-Ca, (F) Example $\mu \mathrm{XRD}$ results of As-bearing Fe and Mn oxides lepidocrocite and jacobsite, respectively, and illite.

Figure 6: GVL8 (48-52 cm depth)(A)Petrographic image (TL/RL) of area targeted for synchrotron analyses,(B)Tricolor $\mu$ XRF maps for As-Fe-Ca and Mn-Fe-Ca; (F)Example $\mu$ XRD results: As-bearing Fe and Mn oxide mixture of lepidocrocite, akaganeite, and birnessite. GVL9 (35-39 cm depth) (D)Petrographic image (TL/RL) of area targeted for synchrotron analyses; (E)Tricolor $\mu$ XRF map for As-Fe-Ca; (F) Example $\mu$ XRD results: As-bearing goethite.

Figure 7: GVL8 (48-52 cm depth) (A) Petrographic image (TL/RL) of area targeted for synchrotron analyses;(B)Tricolor $\mu$ XRF maps for As-Fe-Ca;(C)Example $\mu$ XRD results:realgar, As-bearing lepidocrocite and akaganeite, and a mixture of lepidocrocite, realgar, greigite, and 
fougerite. GVL8 (99-103 cm depth) (D)Petrographic image (TL/RL) of area targeted for synchrotron analyses;(E)Tricolor $\mu \mathrm{XRF}$ maps for As-Fe-Ca;(F)Example $\mu \mathrm{XRD}$ results: mixture of realgar, mackinawite, greigite, fougèrite, gypsum and mixture of lepidocrocite, realgar, greigite, and siderite. Note: Shadow on the rings is an effect from the beamline.

Figure 8: Dissolved metals vs. $\mathrm{pH}$ from pore waters associated with each tailings type. (A) $\mathrm{As}_{\mathrm{T}}$ vs. $\mathrm{pH} .(\mathrm{B}) \mathrm{Fe}_{\mathrm{T}}$ vs. $\mathrm{pH}$.(C) Ca vs. $\mathrm{pH}$.(D) $\mathrm{SO}_{4}{ }^{2-}$ vs. $\mathrm{pH}$. Gray symbols indicate value at detection limit.

Figure 9: Dissolved metals vs. Eh from pore waters associated with each tailings type. (A) $\mathrm{As}_{\mathrm{T}}$ vs. Eh. (B) $\mathrm{Fe}_{\mathrm{T}}$ vs. Eh. (C) Ca vs. Eh. (D) $\mathrm{SO}_{4}{ }^{2-}$ vs. Eh.Gray symbols indicate value at detection limit.

Figure 10: Tailings bulk chemistry plotted on ternary diagrams with theoretical compositions of minerals identified by XRD. Armangite (ARM), arsenopyrite (ASP), birnessite (BIR), Fe oxides (Fe OX), fougèrite (FOU), greigite (GRE), gypsum (GYP), jacobsite (JAC), mackinawite (MAC), pyrite (PYR), realgar (REA), siderite (SID), scorodite (SCO), tooeleite (TLT), yukonite (YUK). Data for wetland tailings is from Kavalench (2010) and Parsons et al. (2012).

\section{Appendix A. Supplementary material}

Table S1:Selected bulk chemistry results from Montague (MG) core samples.

Table S2:Selected bulk chemistry results from Goldenville (GV) core samples.

Table S3:Pore water field parameters collected from Montague and Goldenville in 2009 and selected dissolved metals and As and Fe speciation. Concentrations are in $\mathrm{mg} / \mathrm{L}$ unless otherwise noted. Note: dashes indicate insufficient sample for an analysis; values for S(-II) and Fe(II) may be slightly higher than reported - see Section 2.2.

Table S4:Summary of corresponding water chemistry, mineralogy, and bulk chemistry of tailings from selected locations for depth comparisons. Minerals: Akaganéite (AKA), Armangite (ARM), Arsenopyrite (ASP), Birnessite (BIR), Fougèrite (FOU), Goethite (GOE), Greigite (GRE), Gypsum (GYP), Jacobsite (JAC), Lepidocrocite (LEP), Mackinawite (MAC), Pyrite (PYR), Realgar (REA), Siderite (SID), Scorodite (SCO), Tooeleite (TLT), Yukonite (YUK).Note:Values for S(-II) and Fe(II) may be slightly higher than reported - see Section 2.2. 
Figure 1

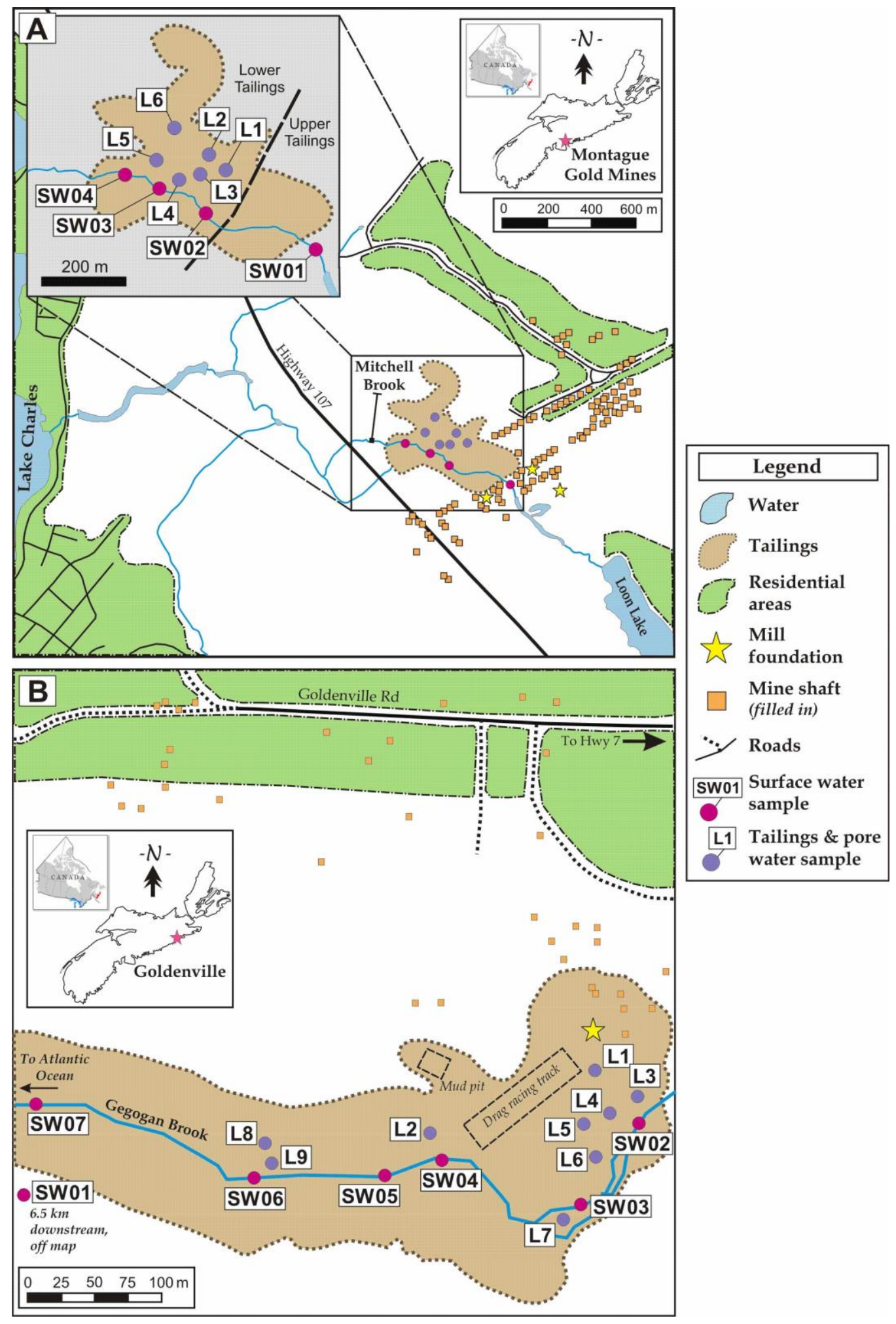




\section{Figure 2}
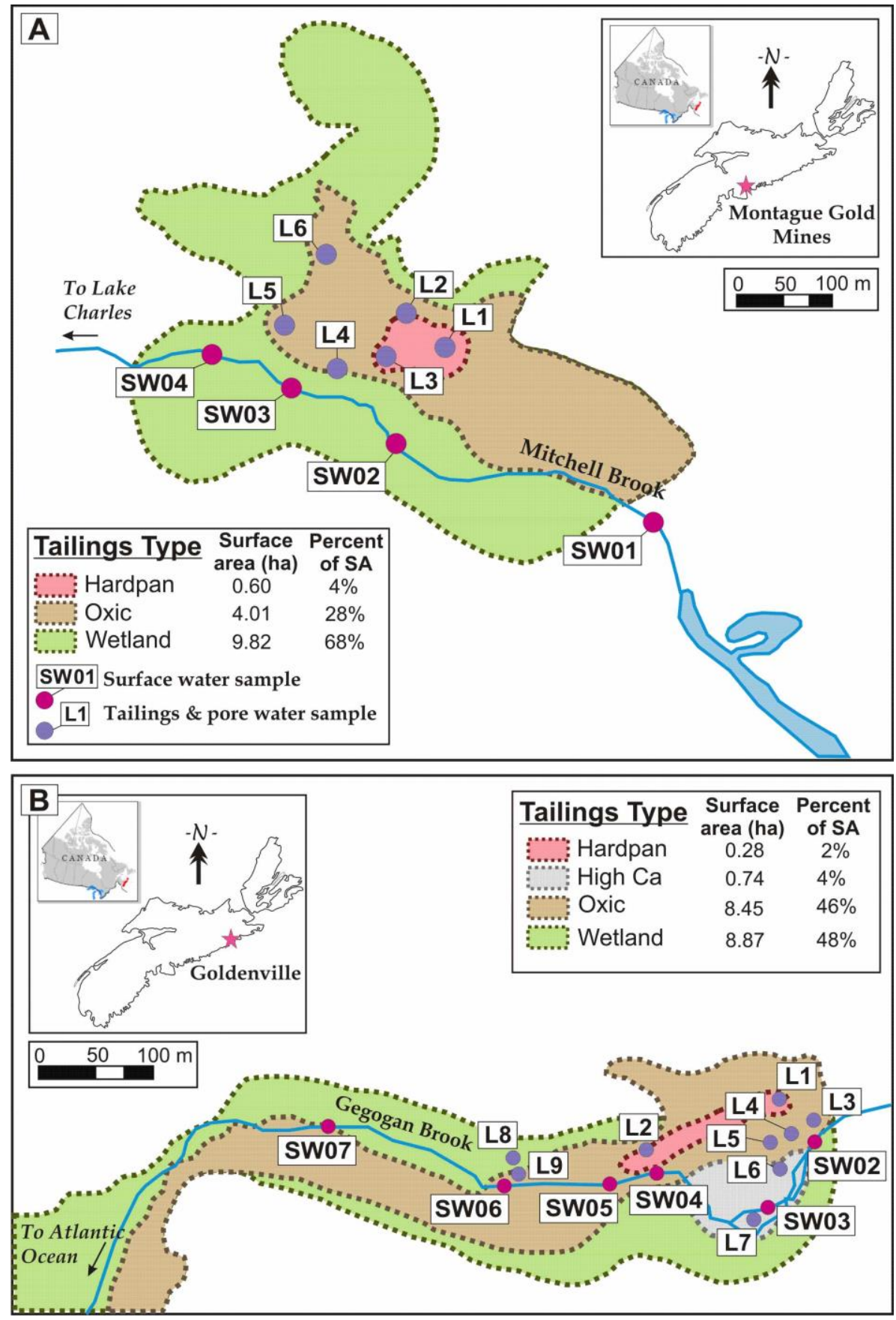
Figure 3
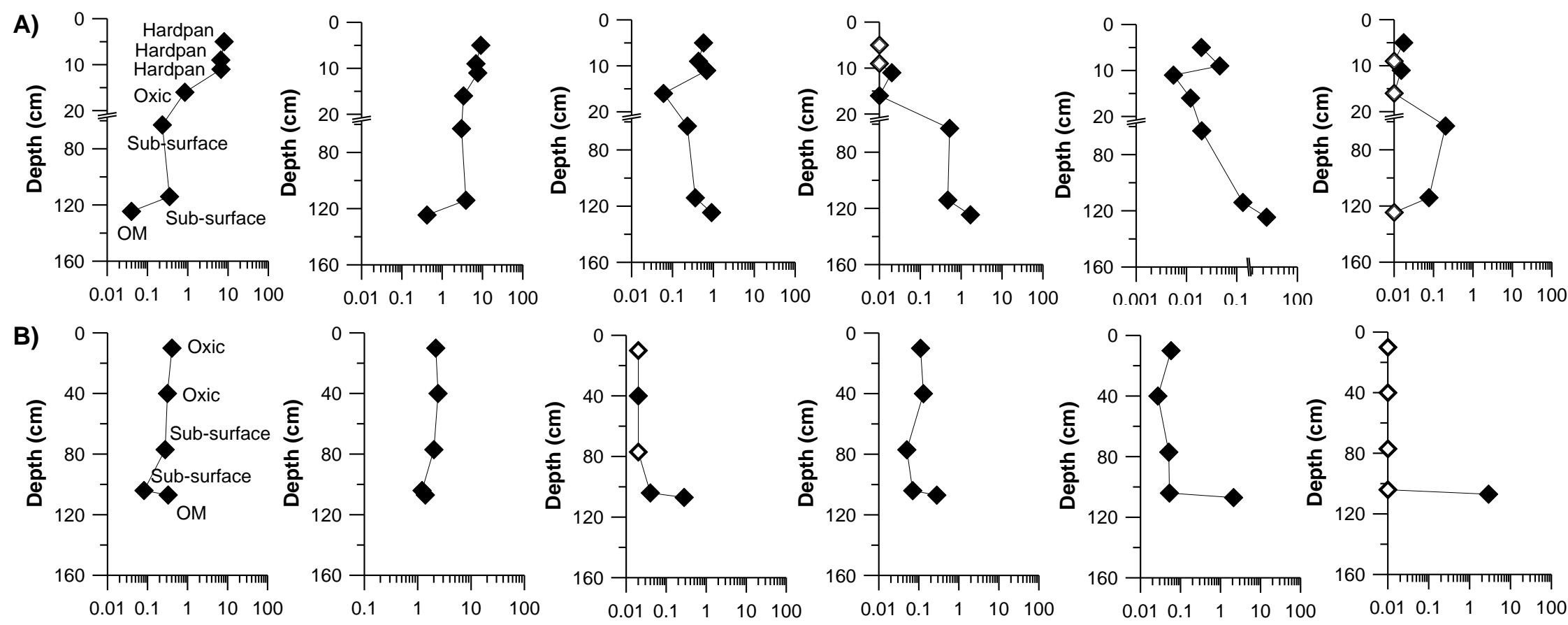

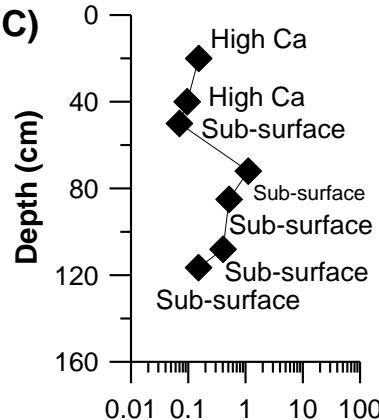

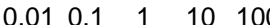
As (wt.\%)
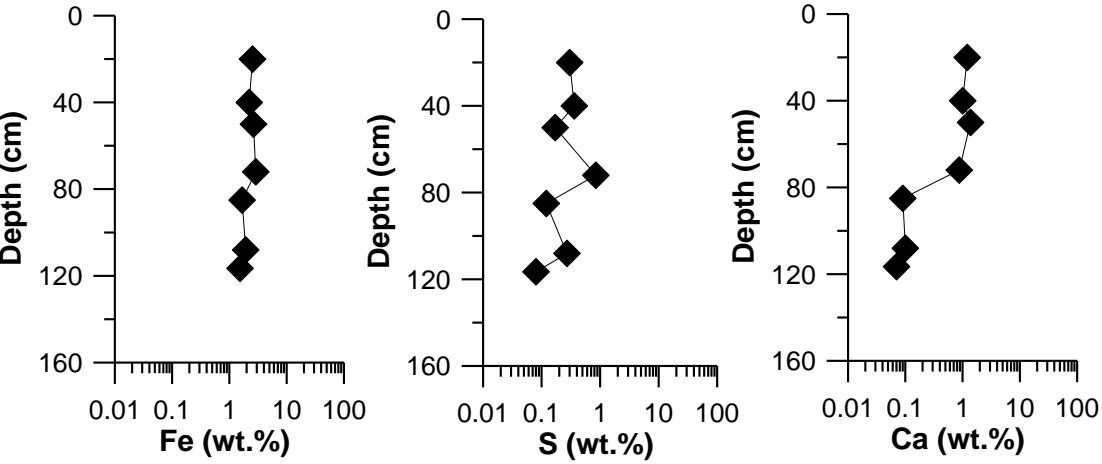

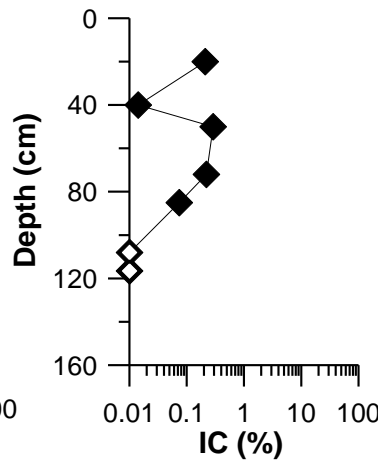


Figure 4
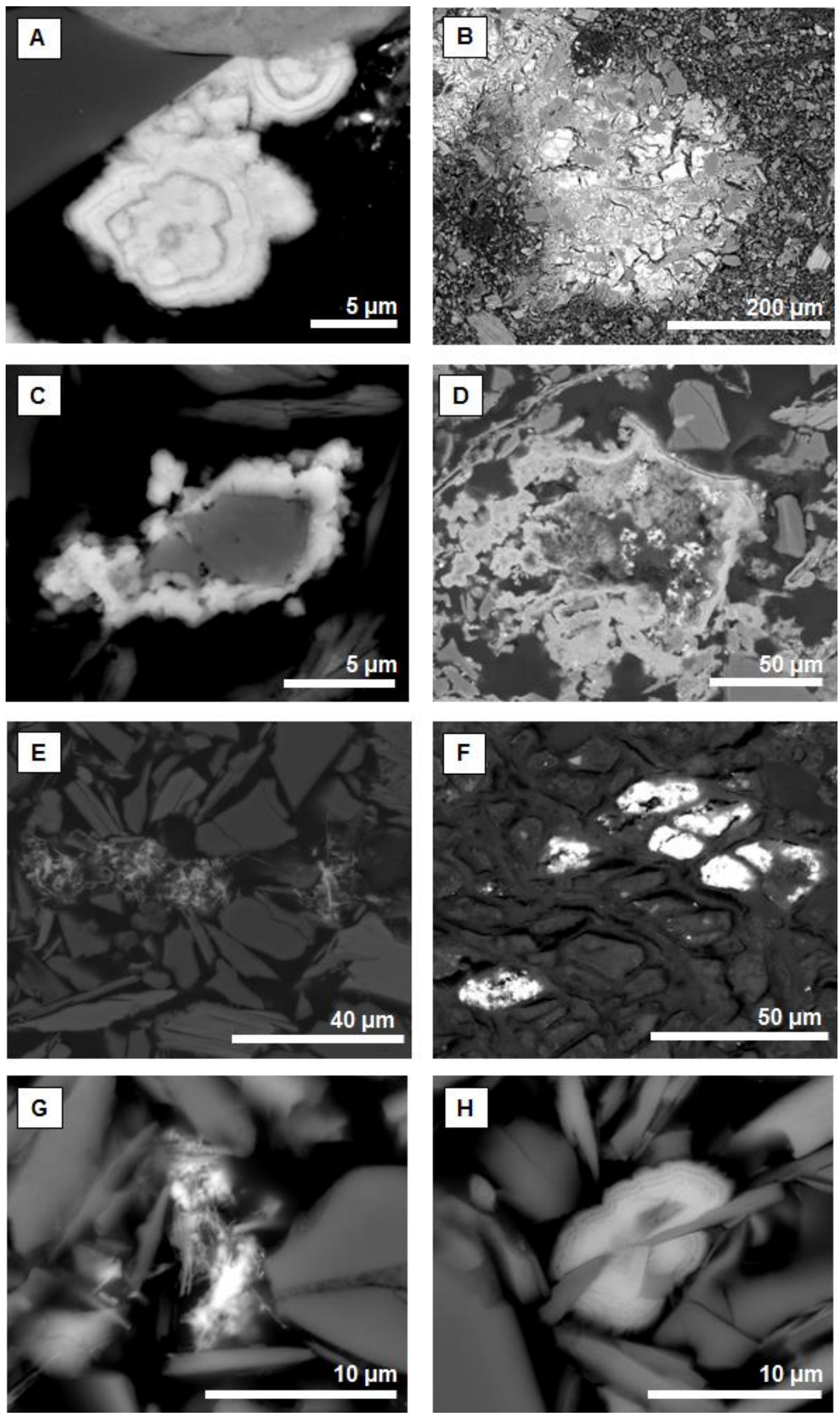


\section{Figure 5}

A)

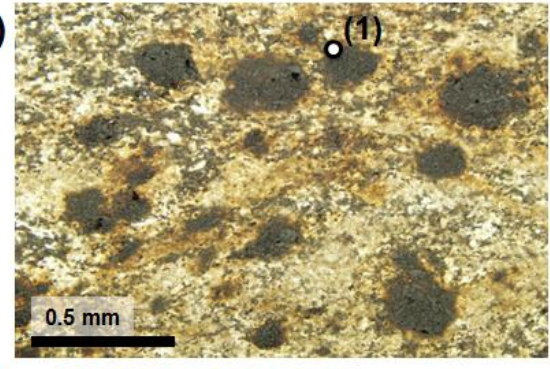

B)

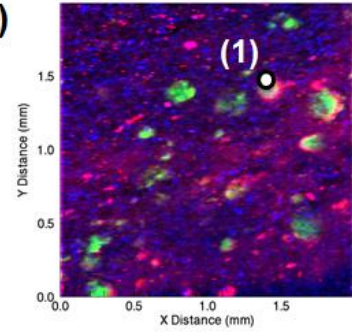

C)

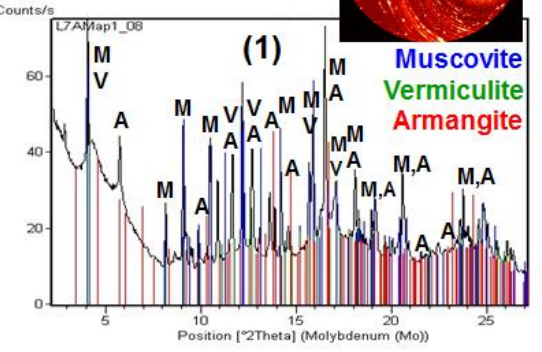

D)

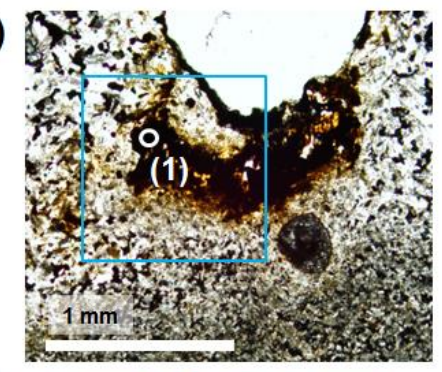

E)
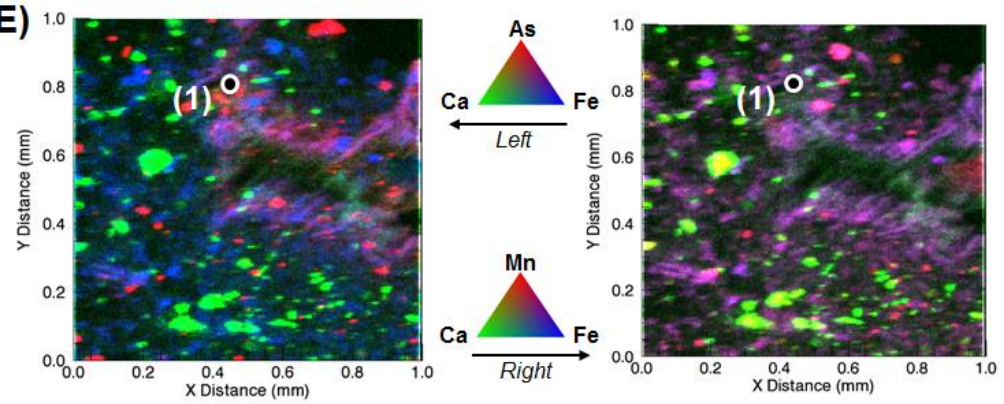

F)

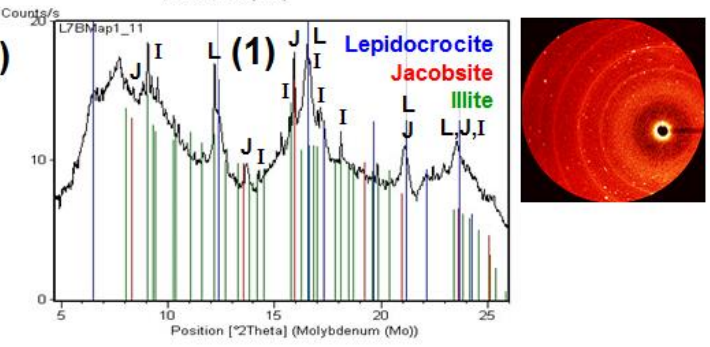


Figure 6

A)

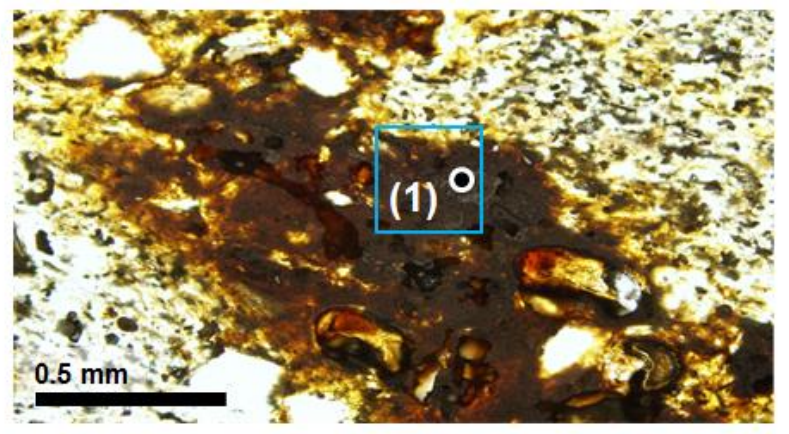

B)

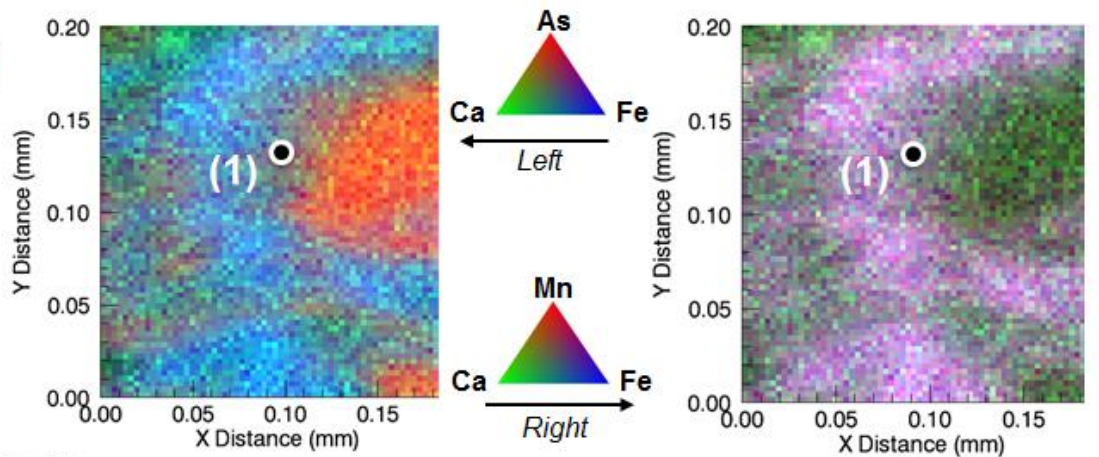

C)

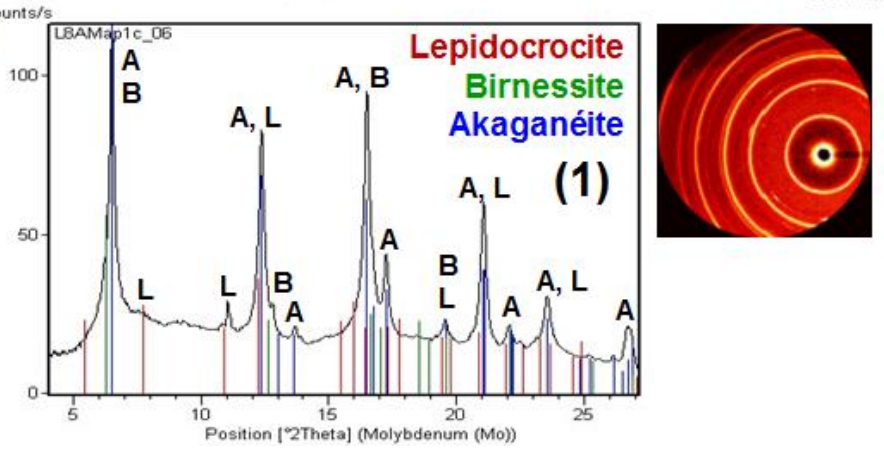

D)

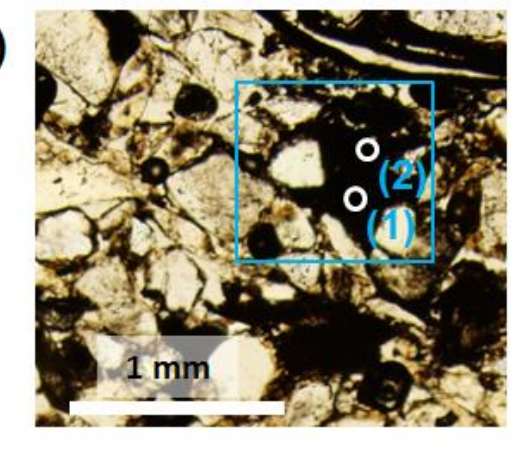

E)

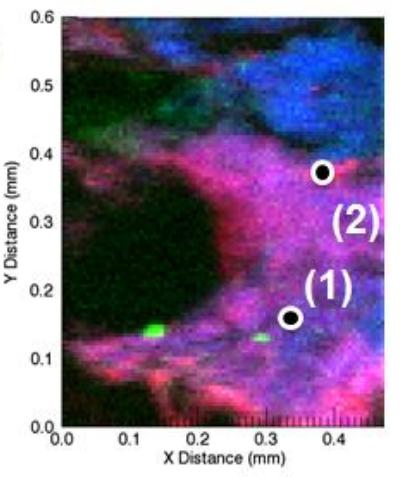

F)

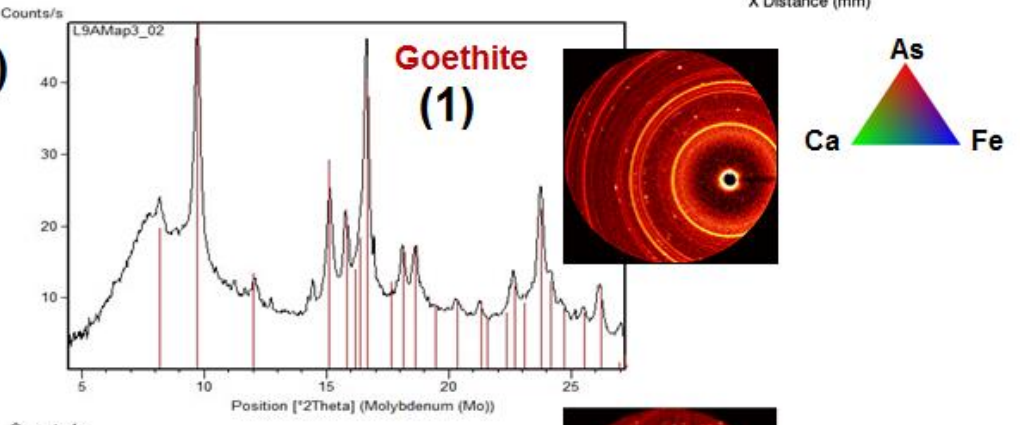

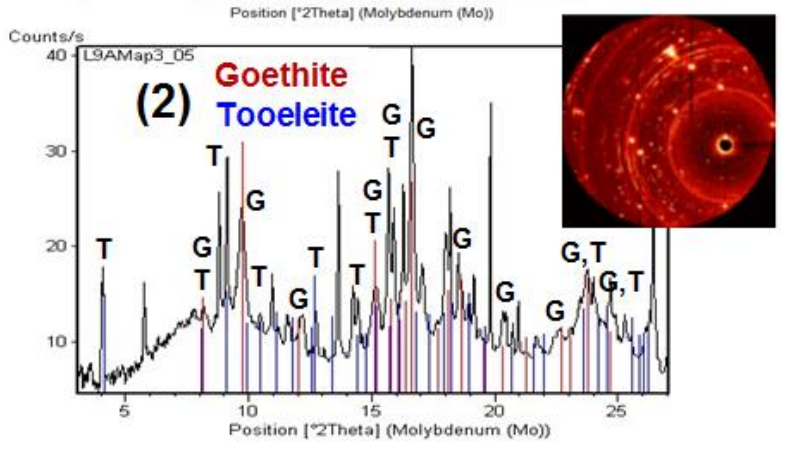


Figure 7
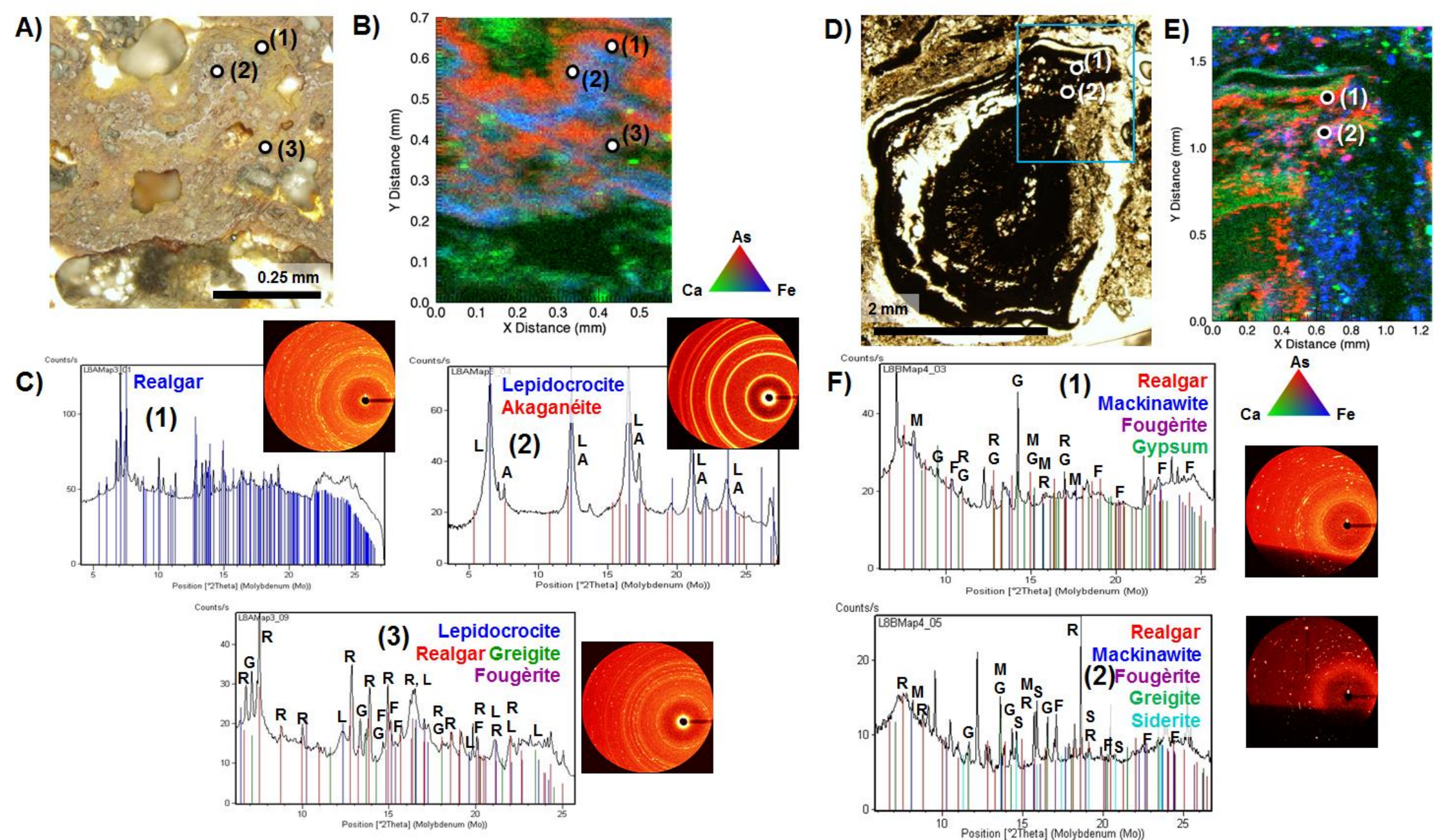
Figure 8
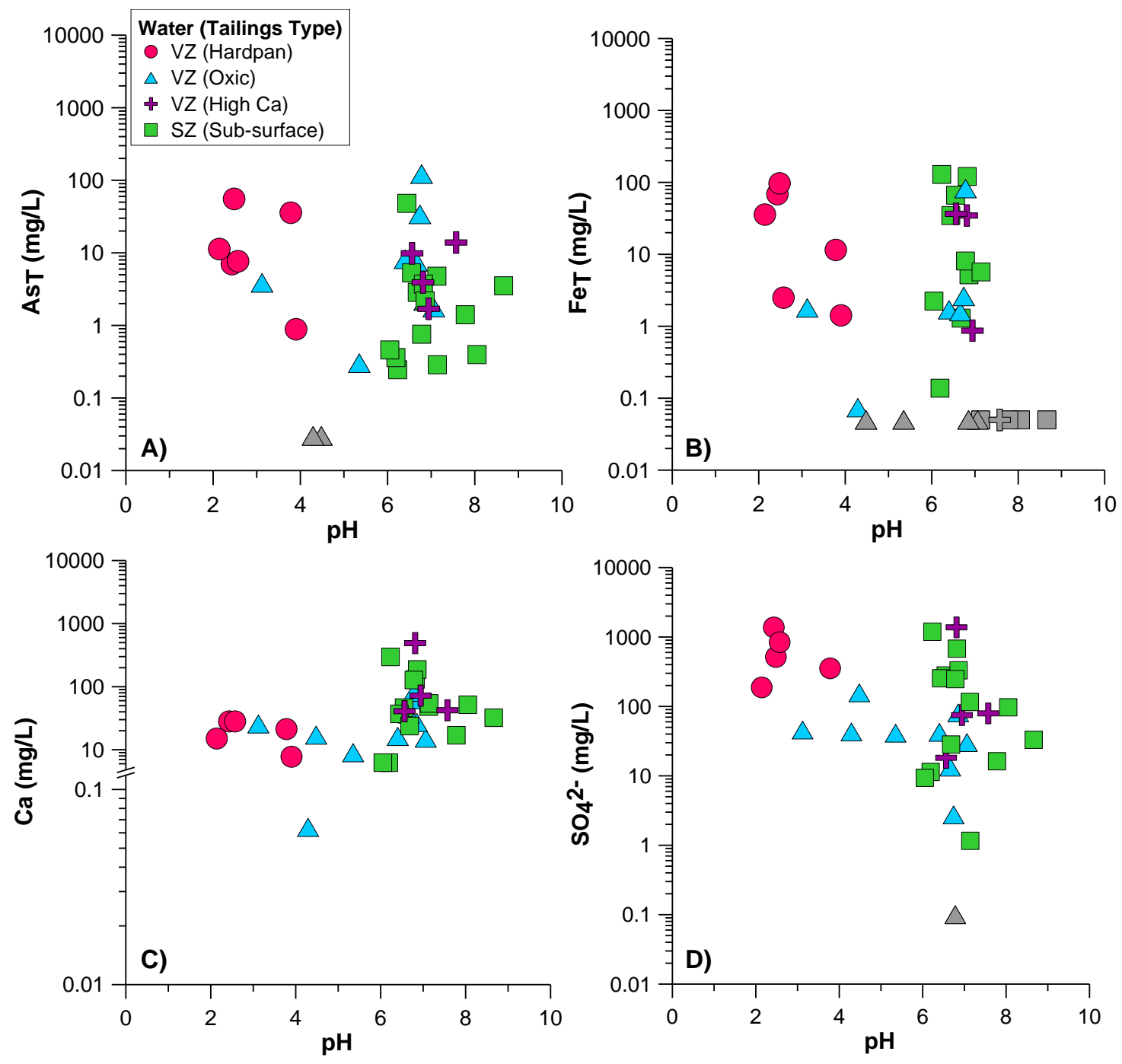
Figure 9
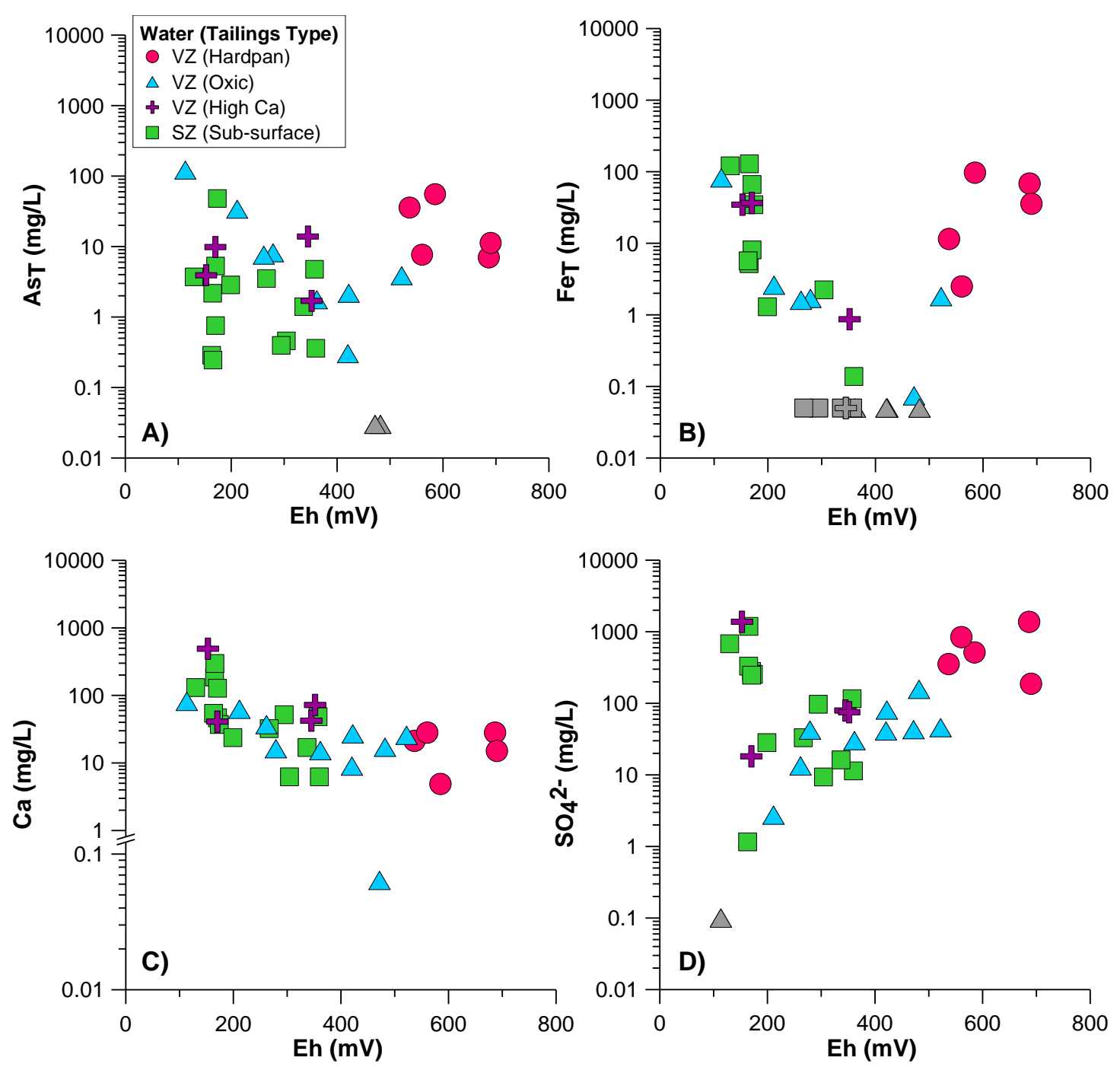


\section{Figure 10}
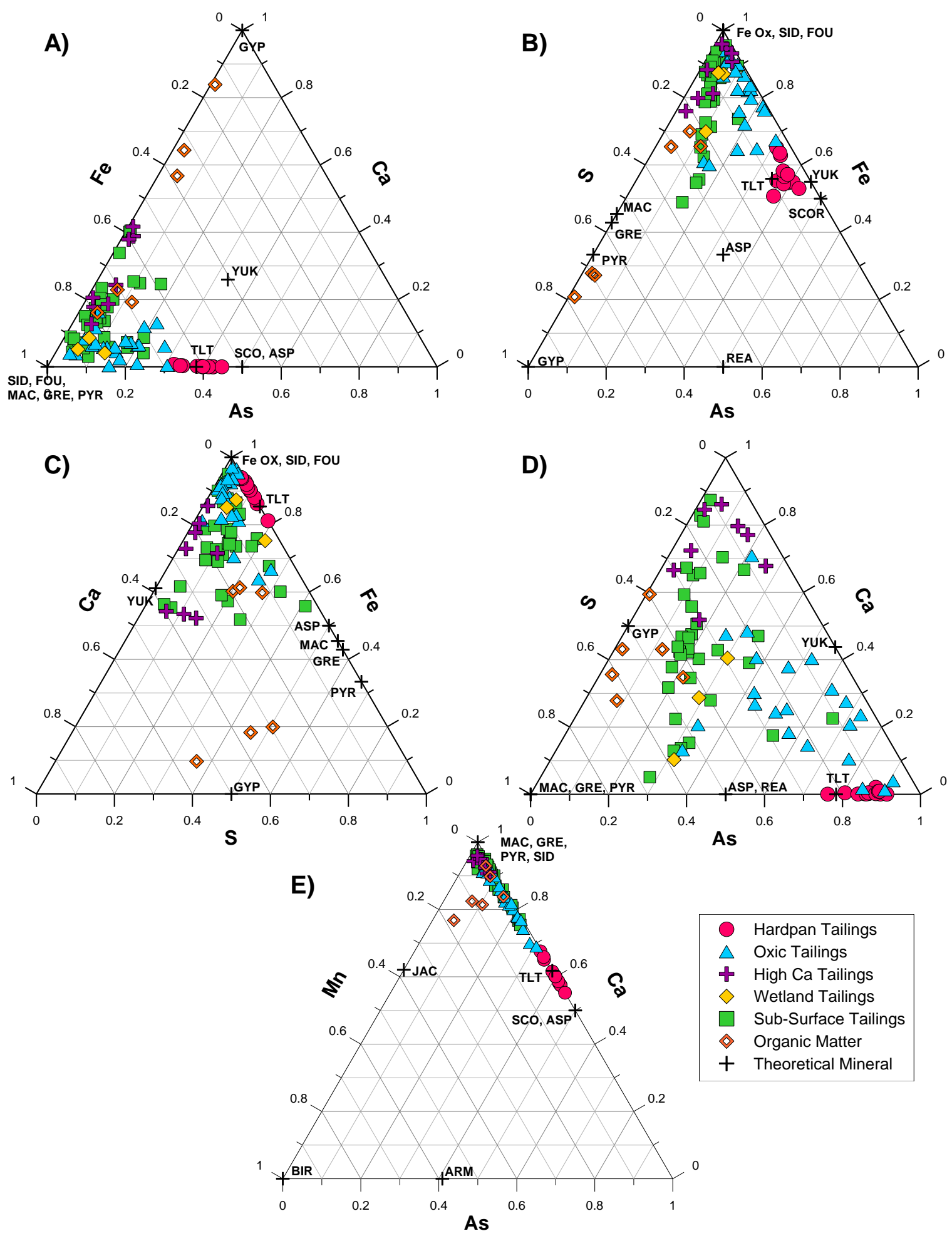

Hardpan Tailings

- Oxic Tailings

+ High Ca Tailings

$\checkmark$ Wetland Tailings

$\square$ Sub-Surface Tailings

- Organic Matter

+ Theoretical Mineral 


\section{Table 1}

\begin{tabular}{|c|c|c|c|c|c|c|c|c|c|c|c|c|}
\hline & \multicolumn{2}{|c|}{ As-Fe } & \multicolumn{2}{|c|}{ As-S } & \multicolumn{2}{|c|}{ Fe-S } & \multicolumn{2}{|c|}{ As-Ca } & \multicolumn{2}{|c|}{$\mathrm{Ca}-\mathrm{OC}$} & \multicolumn{2}{|c|}{ Ca-IC } \\
\hline & $\mathbf{r}$ & p-value & $\mathbf{r}$ & p-value & $\mathbf{r}$ & p-value & $\mathbf{r}$ & p-value & $\mathbf{r}$ & p-value & $\mathbf{R}$ & p-value \\
\hline \multicolumn{13}{|c|}{ Hardpan tailings near surface } \\
\hline MGL1 & 0.99 & 0.02 & 0.27 & 0.32 & 0.31 & 0.001 & -0.65 & 0.43 & 0.81 & 0.59 & 0.94 & 0.02 \\
\hline MGL3 & 0.98 & 0.38 & 0.81 & 0.07 & 0.86 & 0.002 & -0.74 & 0.06 & 0.55 & 0.36 & 0.88 & 0.17 \\
\hline GVL1 & 0.99 & 1.00 & 0.65 & 0.01 & 0.70 & 0.004 & 0.99 & 0.004 & -0.10 & 0.02 & 0.46 & 0.04 \\
\hline GVL2 & 1.00 & 0.52 & 0.99 & 0.01 & 0.99 & 0.002 & 1.00 & 0.01 & 0.82 & 0.59 & -0.56 & 0.67 \\
\hline \multicolumn{13}{|c|}{ Oxic tailings near surface } \\
\hline MGL2 & 0.34 & 2.7E-05 & 0.68 & 0.97 & -0.22 & 2.6E-05 & 0.02 & 0.33 & -0.48 & 0.39 & 0.84 & 0.002 \\
\hline MGL4 & 0.99 & 0.01 & 0.52 & 0.23 & 0.44 & 4.7E-04 & -0.12 & 0.27 & 0.23 & 0.04 & 0.96 & 0.01 \\
\hline MGL5 & 0.89 & 0.01 & 0.30 & 0.68 & 0.67 & 0.01 & -0.48 & 0.33 & -0.05 & 0.37 & -0.83 & 0.08 \\
\hline MGL6 & 0.79 & 2.5E-04 & 0.57 & 0.21 & 0.01 & 5.0E-05 & 0.03 & 0.15 & -0.16 & 0.33 & 0.69 & 2.9E-05 \\
\hline GVL3 & 0.90 & 1.8E-04 & -0.91 & 0.03 & -0.95 & 7.4E-05 & 0.90 & 0.05 & -0.57 & 0.45 & 0.37 & 0.45 \\
\hline GVL4 & 0.83 & 1.0E-04 & 0.83 & 0.06 & 1.00 & 5.2E-05 & 0.83 & 0.76 & 0.73 & 0.04 & 0.94 & 0.02 \\
\hline GVL5 & 0.44 & 3.7E-05 & -0.27 & 0.30 & 0.04 & 7.2E-06 & 0.44 & 0.43 & 0.16 & 0.13 & 0.98 & 0.18 \\
\hline GVL8 & 0.82 & 1.7E-05 & 0.98 & 0.68 & 0.83 & 1.3E-05 & 0.82 & 0.09 & -0.09 & 0.84 & -0.05 & 0.12 \\
\hline GVL9 & -0.49 & 2.6E-04 & 0.49 & 0.55 & -0.64 & 2.4E-04 & -0.49 & 0.92 & 0.62 & 0.23 & 0.20 & 0.04 \\
\hline \multicolumn{13}{|c|}{ High Ca tailings near surface } \\
\hline GVL6 & 0.32 & 5.6E-06 & 0.78 & 0.77 & 0.72 & 1.5E-06 & 0.32 & 0.24 & 0.36 & 0.03 & 0.76 & 0.03 \\
\hline GVL7 & 0.44 & 4.2E-04 & -0.86 & 0.31 & 0.00 & 3.6E-04 & 0.44 & 0.02 & 0.24 & 0.04 & 0.70 & 0.01 \\
\hline
\end{tabular}




\section{Table 2}

\begin{tabular}{|c|c|}
\hline \multicolumn{2}{|l|}{ Sulfides } \\
\hline Arsenopyrite & FeAsS \\
\hline Pyrite & $\mathrm{FeS}_{2}$ \\
\hline Realgar & $\mathrm{As}_{4} \mathrm{~S}_{4}$ \\
\hline Mackinawite & FeS \\
\hline Greigite & $\mathrm{Fe}_{3} \mathrm{~S}_{4}$ \\
\hline \multicolumn{2}{|l|}{ Carbonates } \\
\hline Siderite & $\mathrm{FeCO}_{3}$ \\
\hline Fougèrite & $\mathrm{Fe}^{2+}{ }_{4} \mathrm{Fe}^{3+}{ }_{2}(\mathrm{OH})_{12}\left(\mathrm{CO}_{3}\right) \cdot 3 \mathrm{H}_{2} \mathrm{O}$ \\
\hline \multicolumn{2}{|l|}{ Iron Oxides } \\
\hline Goethite & $\alpha-\mathrm{FeOOH}$ \\
\hline Akaganéite & $\beta-\mathrm{FeOOH}$ \\
\hline Lepidocrocite & $\mathrm{y}-\mathrm{FeOOH}$ \\
\hline \multicolumn{2}{|c|}{ Manganese Oxides } \\
\hline Birnessite & $(\mathrm{Na}, \mathrm{Ca})_{0.5}\left(\mathrm{Mn}^{4+}, \mathrm{Mn}^{3+}\right)_{2} \mathrm{O}_{4} \cdot 1.5 \mathrm{H}_{2} \mathrm{O}$ \\
\hline Jacobsite & $\left(\mathrm{Mn}^{2+}, \mathrm{Fe}^{2+}, \mathrm{Mg}\right)\left(\mathrm{Fe}^{3+}, \mathrm{Mn}^{3+}\right)_{2} \mathrm{O}_{4}$ \\
\hline \multicolumn{2}{|l|}{ Sulfates } \\
\hline Tooeleite & $\mathrm{Fe}^{3+}{ }_{6}\left(\mathrm{As}^{3+} \mathrm{O}_{3}\right)_{4}\left(\mathrm{SO}_{4}\right)(\mathrm{OH})_{4} \cdot 4 \mathrm{H}_{2} \mathrm{O}$ \\
\hline Gypsum & $\mathrm{CaSO}_{4} \cdot 2 \mathrm{H}_{2} \mathrm{O}$ \\
\hline \multicolumn{2}{|l|}{ Phyllosilicates } \\
\hline Arsenic in $\mathrm{gr}$ & oatings and sorbed to surfaces \\
\hline
\end{tabular}


Table 3

\begin{tabular}{lcccccccc}
\hline & Goethite & Lepidocrocite & Birnessite & Greigite & Mackinawite & Siderite & Green Rust & Gypsum \\
\hline MGL2VZ & 7.47 & 2.87 & -6.48 & -- & --- & -3.79 & -11.5 & -1.87 \\
MGL2SZ & 7.95 & 3.45 & -5.88 & -22.69 & -10.8 & -3.65 & -8.72 & -3.99 \\
\hline MGL5VZ & 7.49 & 2.87 & -13.0 & 16.2 & 0.57 & -0.44 & -1.24 & -2.63 \\
MGL5SZ & 7.77 & 3.14 & -8.22 & -279 & -74.5 & -2.62 & -6.87 & -2.73 \\
GVL7VZ & 9.87 & 5.17 & -15.6 & 18.2 & 0.43 & 0.35 & 6.14 & -0.13 \\
GVL7SZ & 10.5 & 5.81 & -15.8 & 19.3 & 0.51 & -0.30 & 7.25 & -0.17 \\
GVL8VZ & 10.4 & 5.86 & -17.4 & --- & --- & -0.35 & 5.70 & -4.54 \\
GVL8SZ & 9.13 & 4.59 & -15.4 & 18.1 & 0.35 & -0.37 & 2.93 & -0.83 \\
GVL9VZ & 9.81 & 5.29 & -15.9 & 21.8 & 1.16 & 0.10 & 5.77 & -2.45 \\
GVL9SZ & 9.34 & 4.81 & -14.9 & 16.8 & -0.24 & -0.74 & 2.43 & -1.05 \\
\hline
\end{tabular}

